\title{
Observing Genre in Archaic Greek Skolia and Vase-Painting*
}

\author{
Gregory S.Jones
}

\begin{abstract}
Skolion. A rather general term covering any after-dinner song; indeed, poems originally written for entirely different purposes (for example poems by Stesichorus) could be performed by a guest as a contribution to the entertainment, and called a skolion. The name comes from the irregular or 'crooked' order in which such pieces were offered during the evening, as opposed to the regular order $\dot{\pi} \pi \dot{\delta} \delta \xi \xi \dot{\alpha}$ in which everyone gave their compulsory piece after dinner. ${ }^{1}$
\end{abstract}

\section{Introduction}

Fowler's definition reflects a longstanding view held by a majority of scholars who have studied songs called skolia but generally assume that the term oxó$\lambda$ เov lacked any real generic significance in antiquity. ${ }^{2}$ Perhaps because of their well-known depictions in comedy (where their popularity among the masses appears to have been exploited for laughs), the Attic skolia are regularly trivialized as 'light' and 'informal' compared to other types of melic poetry, giving rise to a sweeping and often negative generalization of the term skolion that even

* I would like to thank the organizers, hosts, and participants of the conference at Delphi for facilitating such an enjoyable and stimulating event. I am especially grateful to Richard Martin, Alan Shapiro, and Vanessa Cazzato for helpful suggestions and conversations on many aspects of this paper. The present study incorporates several arguments first presented in my dissertation 'Singing the Skolion: a Study of Poetics and Politics in Ancient Greece' (2008 PhD diss., Johns Hopkins University). All translations are my own.

1 Fowler (1987) 93.

2 Notable exceptions include Smyth (1900) xcv-cvii, Bowra (1935), Van Groningen (1960), and Cingano (2003), though none offers a systematic definition of the genre relative to other lyric forms.

(C) GREGORY S. JONES, 2016 | DOI: 10.1163/9789004314849_007

This is an open access chapter distributed under the terms of the Creative Commons Attribution-

Noncommercial 3.o Unported (CC-BY-NC 3.o) License. 
skews the way many of Pindar's songs are perceived. ${ }^{3}$ This consensus derives largely from the work of Richard Reitzenstein (1893) and A.E. Harvey (1955) whose conclusions, provided one accepts them, preclude asking further questions about genre, original function, and the compositional pattern of songs known as skolia: if these songs only acquired that label in their after-supper afterlife as a kind of recycled lyric, then the choice of song and its link to the occasion would seem arbitrary indeed.

In this paper I offer a fresh analysis of the skolion based on current methodological approaches to genre. ${ }^{4}$ Using a wider variety of sources, including archaic red-figure vase painting, I arrive at a more restrictive definition of the skolion and reveal its proper status as a distinct and serious genre within the canon of Greek lyric poetry. Like the paian or threnos, the skolion exhibits a recognizable pattern of composition and performance that was known and respected in antiquity. I shall argue that ancient Greek singers and their audiences began in the late sixth century ВСЕ to distinguish the skolion from other forms of lyric poetry through differences of occasion, content, and style, specifically, the ritual aspects of communal symposia, $\mathrm{proverbial/gnomic} \mathrm{content,} \mathrm{and}$ a preponderance of Aeolic meters coupled with a preference for the Lydian and Ionian modes. ${ }^{5}$ This new generic awareness is most clearly reflected in the emerging pan-Hellenic musical tradition that projected the origins of fixed poetic genres into the quasi-mythical past where Terpander is said to have

3 In reference to Pindar's skolion for Xenophon (fr. 122 S.-M.), Carey (2009) 31-32 observes that 'already by Pindar's date (to judge by Aristoph. Ach.532, Wasps 1222, 1236-1240, Frogs 1302) the term skolion was in general use to designate more informal songs sung at the symposion. He goes on to say that ' $[\mathrm{i}] \mathrm{t}$ would be naive to suppose that Pindar seriously regarded this elaborate professional composition as equivalent to these light songs and we may reasonably doubt that he seriously termed it a skolion'. This reading unduly privileges not only the Attic usage, but also its comic representation. Other scholars treat Pindar's skolia as light and playful in contrast to the rest of his poetry. See Van Groningen (1960) 20-21; Kurke (1996) 69 n. 6.

4 As recent scholarship has emphasized, Greek genre concepts were fluid and changed over time. In the archaic period, occasion and the circumstances of performance created what Depew and Obbink (2000) 6 call 'a conceptual orienting device that suggests to a hearer the sort of receptorial conditions in which a fictive discourse might have been delivered'. Cf. Nagy (1994-1995). Moreover, the 'metadiscourse about genre' which developed in the late classical and Hellenistic periods often distorted or even fictionalized a poem's original 'productions-and performance-based' generic identity; Depew and Obbink (2000) 3. Cf. Rutherford (2001) 4-6; Yatromanolakis (2004). At the same time, however, content and style cannot be wholly divorced from the formation of genre concepts. See Nagy (1990) 99; Carey (2009) 23-24.

5 Cf. Yatromanolakis (2009). 
invented the skolion (in a lost poem by Pindar; Ps.-Plut. de musica 1140f.). Within the group of vases relating to this generic tradition, I identify an early reference to Terpander's legendary invention of the barbitos and its association with the skolion on a red-figure kylix by the Epeleios Painter (ca. 500 BCE). We may note from the outset that the invention of a creation myth for the skolion is a conceptual leap that requires an a priori understanding of what a skolion is, how it is to be defined, and what separates it from other named forms of poetry.

\section{Previous Scholarship}

Before offering a new assessment of the skolion's generic identity, it would be helpful to review briefly some of the major arguments and approaches to the subject advanced by earlier critics. By convention I begin with the two pieces of ancient scholarship that have exerted the most influence on modern studies. The first is a set of Hellenistic etymologies by Dikaiarchos and Aristoxenos preserved together in a single paraphrase (schol. Pl. Gorg. 451e p. 207 Cufalo):

In his treatise On Musical Competitions Dikaiarchos (fr. 88 Wehrli) says

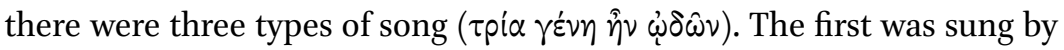
everyone, the second sung individually in order, and the third was sung only by the most skilled performers wherever they happened to be sitting, whereby the song is called a skolion because of this crooked order. But Aristoxenos (fr. 125 Wehrli) and Phyllis the musician say that at weddings they placed many couches around a single table and took turns singing

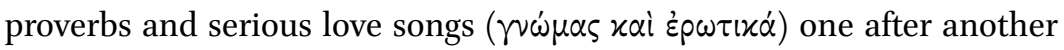
while holding myrtle. The path was crooked due to the placement of the couches in a polygonal room and because those reclining on them were shoved in corners. Therefore it was not because of their composition, but because of the crooked route of the myrtle that the songs are called skolia.

Modern scholars tend to treat these etymologies as an authoritative account of the skolion's generic and performative matrix despite their obvious deficiencies, not least of which is the fact that Dikaiarchos and Aristoxenos did not set out to provide a comprehensive explanation of generic classification and morphology, but merely describe an interesting mode of performance in the service of a rather speculative etymology. Both writers apparently sought an explanation for the skolion's 'crooked' generic nomenclature in that peculiar style of performance well known from Attic comedy in which singers of local Attic sko- 
lia cap the verses of other singers or take turns singing whole songs. ${ }^{6}$ Furthermore, the etymology's stilted division of songs into three genera of performance reflects a penchant for classificatory epistemology no doubt derived from the kind of Aristotelian thinking prevalent in the Lyceum at Athens where Dikaiarchos and Aristoxenos both spent time. It is interesting to note that despite a shared intellectual heritage each etymologist arrived at a different conclusion based on a different explanation of the skolion's variable modes of performance. Indeed, Dikaiarchos' tripartite subdivision of song seems to be more a reflection of Peripatetic methodology than fifth-century reality.

The second piece of evidence consists of a much later discussion of these same etymologies by Plutarch (Q. Conv. 615a-c), whose reworking of the material offers a mystifying jumble of disparate academic notions:

Indeed, the skolia are not a genus of obscurely constructed songs as they say. Rather, everyone first sang a song to the god in unison chanting the paian, and after that the myrtle was passed in turn to each person (the sprig, I think, being called aisakos because the one who takes it sings), after which the lyre was also passed around and anyone who was educated took it and sang, tuning it, while those who were unmusical did not accept it, and so the song was called skolion because it was not sung in common nor was it easy. Others say that the myrtle did not go around in order, but passed from each person from couch to couch. For the first man to sing passed it to the first man on the second couch, and he passed it to the first man on the third couch, and then likewise the second to the second man on the next couch, and so the seeming complexity and bending of the course was called 'skolion'.

Plutarch clearly elaborates upon Dikaiarchos' original etymology and speaks

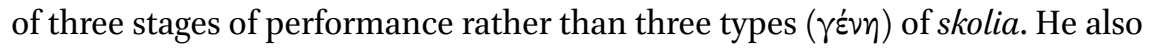
combines the original Peripatetic theory with a competing etymology based on the adjective's (skolios) variant sense of 'hard' or 'difficult.' This particular etymology is preserved in fuller form by the scholiast to Aristophanes' Wasps (1222a Koster):

It was an ancient custom for people at banquets to sing in order, following upon the first man wherever he happened to stop the song. The first man started, holding a sprig of laurel or myrtle and singing a song of Simonides

6 E.g. Ar. Vesp. 1222-1223; Cratin, fr. 254 K.-A. 
or Stesichoros as far as he wished, then handed it on to whomever he wanted but not in the order of the seating arrangement. The man who took it up sang the next verse after the first, and then he passed it along to whomever he wanted. Because everyone sang and recited them without forewarning the songs were called skolia because of the difficulty ( $\tau \dot{\alpha} \mu \dot{\varepsilon} \lambda \eta$

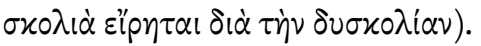

Some modern scholars have tried to reconcile these sources with one another and with earlier descriptions of the skolion found in Attic comedy. In his inaugural treatment of the ancient testimony, Reitzenstein drew heavily upon a well-known passage from the Clouds (1353-1354) in which Strepsiades asks his son to take up the lyre and sing a victory ode by Simonides (PMG 507); when he refuses, Strepsiades asks him to take a sprig of myrtle at least and recite something from Aischylos. Comparing this passage to the etymologies, Reitzenstein argued that Dikaiarchos originally applied the term skolion only to the third class of song performed by the most skilled performers, whom Reitzenstein identified via Aristophanes and Plutarch as those who possessed an ability to play the lyre and sing the more complicated lays of archaic lyric masters. Accordingly, he identified Dikaiarchos' first class of song as the paian and related the second class of song to the short simple verses of the Attic skolia. Conflating this tripartite division of performance with the scenario found in the Clouds-where, it is crucial to note, the term skolion is never used-Reitzenstein concluded that all of the poetry Strepsiades mentions there, including songs by Simonides and passages from Aischylos, were generally grouped together as a single category when performed over wine and called skolia. ${ }^{7}$ However, instead of being an independent source of corroborative evidence, as modern scholars have treated it, this passage from the Clouds and others like it seem rather to have inspired and contaminated later etymologies, which confuse a style of performance with generic nomenclature. No songs by Stesichoros or Simonides are otherwise known as skolia, and the scholiast/etymologist in this case probably never witnessed a live performance of the genre. ${ }^{8}$

7 Reitzenstein (1893) 3-5, 30-31.

8 The scholiast to Plato's Gorgias (451e p. 207 Cufalo) reports that some authorities attribute the Attic skolion on health (PMG 890) to Simonides, others to Epicharmos. Clement of Alexandria (Strom. 4.5.23) attributes it to Simonides or Aristotle (cf. Aristot. Rhet. 1394b). It is telling that Plato does not mention Simonides when quoting this song, referring to its author simply as 'the one who made the skolion' as if he were anonymous. See Fabbro (1995) 25-27. I generally find the scholiasts' attempts to attribute the otherwise anonymous Attic skolia to various 
Five decades later, A.E. Harvey attempted in greater detail to determine the semantic range of the word skolion. ${ }^{9}$ Following closely upon Reitzenstein's examination of Dikaiarchos, Harvey also drew a sharp distinction between the etymologists' second and third class of skolia. He maintained that during the fifth century ВСЕ the term skolion referred to anything performed over wine after dinner. Both Reitzenstein and Harvey believed that the ability to recite the great lyric poets of the archaic past while accompanying oneself on the lyre was in decline during the fifth century $\mathrm{BCE}$, giving rise to the degenerate practice of singing short simple songs and excerpts from tragedy while holding a myrtle sprig, as evidenced in the Clouds and the Wasps. ${ }^{10}$ In trying to determine why after the fourth century вСЕ the term skolion was no longer applied to the songs of archaic lyric masters like Pindar (who called one of his own songs a skolion, and whose other 'banqueting' poems are called skolia by various sources), Harvey concluded that 'the only drinking-songs which remained in use were those which had belonged to the second stage of the fifth-century convivialitiesthe short stanzas in fixed meters, sung by each of the guests in turn, holding in their hands the myrtle-branch instead of the more exacting lyre." ${ }^{\prime 1}$ According to Harvey, 'the word $\sigma x o$ ' $\lambda$ iov soon became restricted to denoting only the second class' when the general decline in musical education all but erased the once dominant practice of entertaining oneself on the lyre. ${ }^{12}$ Harvey's solution has been enormously influential, ${ }^{13}$ but is not beyond dispute. The over-

named poets unconvincing. For example, the scholiast to Ar. Vesp. 1239 Koster reports that some authorities attribute the Admetos song ( $P M G$ 897) to Alkaios or Sappho, though he places it among Praxilla's drinking songs.

10 Reitzenstein's (1893), 32-33 implausible reading of these passages also relies upon an excerpt from Cicero's Tusculan Disputations (1.4) in which the Roman orator reports that every Greek man in the time of Themistokles was educated in music and skilled in the lyre and that such men displayed their talents by playing the instrument 'at banquets' (in epulis). For a more recent and realistic reading of the comic evidence see Kugelmeier (1996) $76-77$, who continues to interpret them as an indication of 'kulturelle Wandel', but lays more emphasis on changing practices rather than strict decline.

11 Harvey (1955) 162.

12 Harvey (1955) 163.

13 Most major studies that touch upon issues of genre and performance begin from the conclusions of Reitzenstein and Harvey: e.g Collins (2004) 84: 'The term itself ... admits of several different usages already in the earliest literary sources.' See also Lambin (1992) 266-307; (1993); Liapis (1996); Teodorsson (1989) 129-131. After the publication of Harvey's article in 1955 , Bowra $\left(1961^{2}\right)$, who once treated the skolion as a distinct genre $\left(1935^{1}\right)$, changed his approach completely and no longer considered it to be a distinct poetic form. 
complicated theory of musical decline seems especially dubious and finds little support in recent work on the cultural history of Greek music. There does seem to have been a move toward trendier contemporary poets in Athens during the last quarter of the fifth century вСЕ, but to see this phenomenon in terms of a general decline in musical abilities seems anachronistic and more reflective of modern tastes than ancient realities. ${ }^{14}$ The real answer to the question of why Alexandrian scholars abandoned the term skolion as a classificatory label may be a simple one: during the fifth and fourth centuries BCE the term skolion denoted a specific lyric genre and was consistently applied to those songs composed and performed in the appropriate manner-but when the skolion ceased to be a living genre in the Hellenistic period, the term and its generic significance were forgotten and most Alexandrian critics simply stopped using it.

\section{A New Approach}

In the half-century since Harvey's decisive declaration that any song sung after dinner could be called a skolion, classicists have developed a more nuanced understanding of the dynamics of genre and the problems of Alexandrian scholarship. We now know, for example, that later Hellenistic discourse on archaic lyric poetry often misrepresented original performance contexts with anachronistic fantasies, or, in the case of Dikaiarchos and the etymologists, distorted the reality of performance through imposed templates of philosophical theory. We are also more sensitive to the elasticity of genre and the variability of factors ancient audiences used, often in unpredictable ways, to categorize different types of poetry. ${ }^{15}$ Bearing this in mind, the skolion looks quite different when viewed from the perspective of classical sources: above all, it looks like

14 See generally Csapo (2004). As Peter Wilson (2004) 295-297 has emphasized: 'We have good evidence for the continued importance throughout the democratic period of the training "young Athenian gentlemen" received from their kitharist'. In fact, instead of degenerating into a boorish den of popular music, the symposion became the locus of aristocratic experimentation and renewed conservatism in late fifth- and early fourthcentury вСе Athens. Wilson draws particular attention to Kritias' musical activities in the latter decades of the fifth century вСE and his move to protect the 'cultural capital' of the lyre and old aristocratic poets like Anakreon.

15 E.g. Carey (2009) 21-22 reminds us that genre categories in archaic and classical Greece were porous and flexible, admitting a great deal of overlap and uncertainty, but enough firmness 'to generate a set of audience expectations'. 
a coherent and relatively stable generic concept. In the first instance, I see no reason to doubt Pindar's sincerity when he calls his song for Xenophon a skolion (fr. 122 S.-M.) in order to distinguish it from, among other things, the ode he wrote in connection with the same Olympic victory (Olympian 13; see below). Moreover, Pindar's story about Terpander being the inventor of the skolion (חiv-

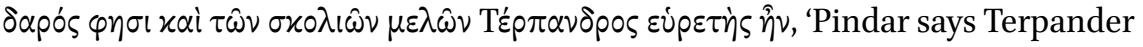
was the inventor of the skolia songs,' Ps.-Plut. de musica 1140 f.) suggests an affinity with the genre stemming from a considerable amount of experience. ${ }^{16}$ Based on Pindar's usage, we may conclude that the term skolion had already become a common genre label applied to new compositions during the first half of the fifth century BCE while also being applied retrospectively to older songs thought to have been composed within the same continuous tradition (as they probably were). Whether or not these older songs were originally called skolia or something else altogether, we may be fairly certain that other Pindaric compositions that fit the mold and are named skolia in later sources carried the same conceptual label as Xenophon's self-named skolion for most audiences from the beginning. We may also note that several passages from Attic comedy apply the term skolion restrictively to a number of songs that are labeled as such elsewhere in Greek literature: the Attic skolia (e.g. PMG 897) and a verse by Alkaios (fr. 141 L.-P.) are named in Wasps (1222-1248; cf. Athen. 693f.-695f.; Ath. Pol. 19.3, 20.5), skolia by Alkaios and Anakreon in Banqueters (fr. 235 K.-A.) and Birds (1410-1416; schol. 1410b Holwerda; Alc. fr. 345 L.-P.; cf. Alc. frr. 249, 348 L.-P.; PMG 891; Arist. Pol. 1285a), and a skolion by Timokreon (PMG 731) in Acharnians (532-534; schol. 532 Wilson). Additionally, in Frogs (1301-1303) Aischylos accuses Euripides of pilfering elements (probably linguistic and acoustic) from all kinds of songs, listing skolia alongside other forms of lyric like threnoi as if they all had unique characteristics that set them apart from one another; if the term skolion referred to any song whatsoever that happened to be performed after dinner then its inclusion here would be nonsensical. What, then, do all of these songs have in common?

To begin our search for an answer, let us turn (very carefully) to Athenaios, who echoes the old tripartite subdivision of Dikaiarchos' etymology, but frames the discussion in a way that adds consilient information about the nature of the skolion (694c):

16 Power (2010) 410 has suggested that Pindar's attribution of the skolion to Terpander belongs to the same skolion for Hieron (fr. 125 S.-M.) in which the poet credits him for inventing the barbitos. 
Most of the guests remembered the well-known Attic skolia, which are worth recounting because of their extreme archaizing and the simplicity

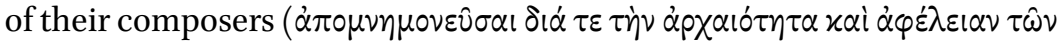
$\pi \circ \eta \eta \sigma \alpha ́ v \tau \omega)$. Alkaios and Anakreon are praised for this type of composition ( $\tau \hat{\eta} i \delta \dot{\varepsilon} \alpha \tau \alpha v i \eta \eta$ ) as Aristophanes shows in the Banqueters when he says, 'sing to me a skolion, choosing something from Alkaios or Anakreon.' Praxilla of Sicyon is also highly regarded for her composition of skolia. They are called skolia, not because their pattern of composition was crooked-for the skolia are said to be a relaxed form of song ( $\lambda \varepsilon \dot{\gamma} \gamma$ - volv

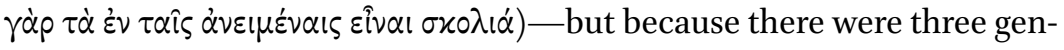
era, as Artemon of Cassandreia says in Book 2 of On the Use of Books (FHG IV 342), which includes the songs associated with social gatherings ( $\tau \dot{\alpha}$

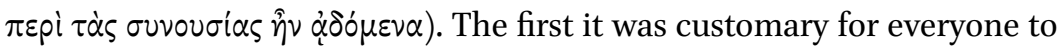
sing, the second type everyone sang also, but in order, one taking it over from another, and as for the third and most highly ranked type, not everyone participated, but only those who seemed sagacious, whatever place they happened to be in (...) This kind was sung when they finished the communal songs and the songs it was necessary for everyone to sing, for they would request each of the wise singers to offer a beautiful song to the group. By beautiful, they meant one that seemed to give some advice or

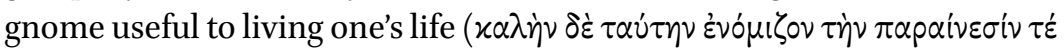

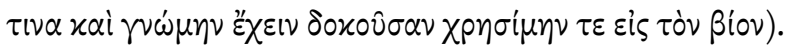

When purged of Peripatetic excess, the combination of Aristoxenos' etymology and Artemon's discussion in Athenaios yields three useful facts about the skolion:1) skolia were customarily performed over wine at communal symposia, 2) their content was characteristically gnomic/proverbial or contained 'serious love-songs', and 3) they were considered to be a relaxed form of song and easy to sing. These three generic elements correspond roughly to the formal concepts of occasion, content, and style/form (meter, melody, etc.), which contribute to the formation of genre categories in both ancient and modern systems of thought. ${ }^{17}$

17 See Nagy (1990) 47-51, 87-88, 98-115; (1994-1995); Yatromanolakis (2004) 6o-62; Kantzios (2005b) 11-29. If occasion was the most important factor in determining archaic genres, by the late classical period content and style became important generic markers, as indicated by Plato's tripartite division of song in the Republic (398d) and Aristotle's (Poet. 1447a) basic approach to distinguishing different genres through different means of representation, such as rhythm, language, and melody. 


\section{The skolion Reconsidered}

\section{Occasion}

In testing this outline of the skolion against the surviving corpus, we may begin with Pindar's skolion for Xenophon, which contains the earliest surviving use of the term $\sigma x \dot{x}^{\lambda} 10 \mathrm{v}$ in Greek literature. ${ }^{18}$ This song was performed at Xenophon's thanksgiving sacrifice in the sanctuary of Aphrodite at Corinth in the wake of his Olympic victory of $464 \mathrm{BCE}$. According to Athenaios (573e-f $=$ Chamaeleon fr. 31 Wehrli):

Pindar first wrote an enkomion for him [Olympian 13] ... but later com-

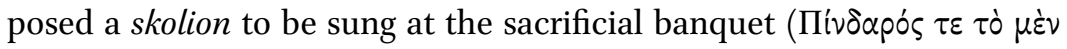

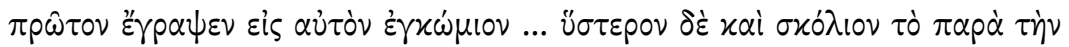
$\theta \nu \sigma i \alpha \nu \dot{\alpha} \sigma \theta \dot{\varepsilon} \nu)$, the beginning of which he composed as an address to the prostitutes who took part in the occasion when Xenophon was presiding over the sacrifice to Aphrodite ...

Athenaios quotes enough verses of the skolion to create a fairly intelligible whole (Pindar fr. 122 S.-M.):

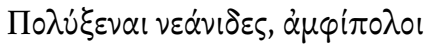

$\Pi \varepsilon i \theta 0 \hat{\varsigma} \varsigma$ ह่v $\alpha \varphi v \varepsilon i \omega \hat{~ K o p i v \theta \omega, ~}$ $\alpha i l \tau \varepsilon \tau \hat{\varsigma} \varsigma \chi \lambda \omega \rho \hat{\varsigma} \varsigma \lambda$ i $\beta \dot{\alpha} v 0 u \xi \alpha \nu \theta \dot{\alpha} \delta \alpha \dot{x} x \eta$

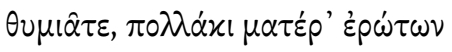

oujpavíav $\pi \tau \dot{\alpha} \mu \varepsilon v \alpha l$

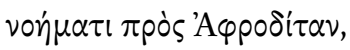

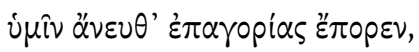

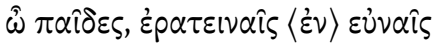

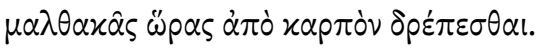

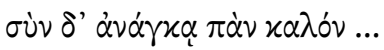

18 West (1974) 7 draws attention to the relatively early use of skolion as a generic term, which he argues reflects the occasion of the songs' performance. E.L. Bowie (1986) 26, on the other hand, maintains that the term 'refers not to the occasion but to the manner of performance of the songs.' 


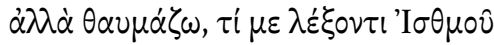

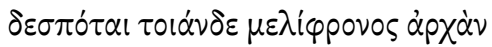

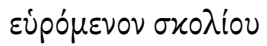

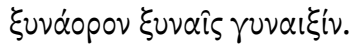

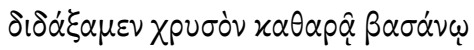

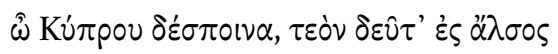

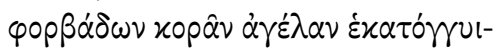

ov $\Xi \varepsilon v 0 \varphi \omega \hat{\nu} \tau \varepsilon \lambda \varepsilon \dot{\alpha} \alpha \zeta$

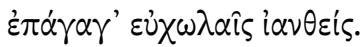

Young girls, much frequented attendants

of Persuasion, in rich Corinth

you burn the yellow tears of pale frankincense

often flying in thoughts up to the mother of desires,

Uranian Aphrodite;

to you she has permitted without blame

to pluck the fruit of soft youth

in welcome acts of love.

Under compulsion everything is beautiful ...

But I wonder what the lords of the Isthmus

will say about me for composing a beginning such as this

for a honey-minded skolion

to accompany common women.

We test gold on a pure touchstone ...

O mistress of Cyprus, here to your grove

A hundred-limbed herd of grazing women

Xenophon has led, rejoicing in the

fulfillment of his prayers. 
Based in part on the songs' respective performance contexts, both Pindar and Athenaios (via Chamaeleon) distinguish this skolion from the earlier enkomion, the skolion having been composed for performance at the banquet, the enkomion as part of the initial victory celebration (probably for performance during a kômos).${ }^{19}$ The skolion is clearly not a victory ode, as it mirrors the occasion of the sacrificial banquet and was most probably performed over wine. ${ }^{20}$ In addressing itself to the sacred prostitutes (perhaps in a spirit not unrelated to that of the skolia erôtika mentioned by Aristoxenos) the song positions itself primarily within the religious community of the sanctuary and the occasion of the feast, moderating Xenophon's original victory. Scholars now agree that Pindar expected his victory odes to be re-performed at a number of different venues, especially symposia, but there is no reason to believe that epinikia were ever called skolia by classical singers and their audiences. Even when performed over wine an epinikion remained an epinikion, just as a skolion remained a skolion even if the person singing it or writing it down were not drinking (e.g. Pl. Gorg. 451e). ${ }^{21}$

19 Van Groningen (1960) 20-21 followed by Kurke (1996) 50, 69 n. 5 rightly interprets the

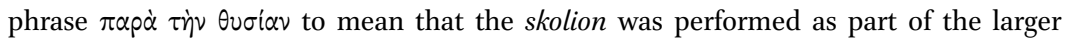
celebrations, not during the actual slaughter ('à côté, en marge du sacrifice' or à l'occasion du sacrifice'). Kurke rightly asserts that the occasion was the symposion. Cf. Fränkel (1973) 469-471; Budin (2006) 85. On the likely performance contexts of Pindar's victory odes see Heath (1988), Heath and Lefkowitz (1991), Carey (1991), and Morgan (1993), who argue in favor of choral performance. Morgan also demonstrates that Pindar (in Olympians 1 and 9) tried to distance his rather serious epinikia from the playful songs and lesser victory odes performed at symposia.

20 Cingano (2003) 24-25 argues that Xenophon's financial resources and the open space of the sanctuary, as opposed to the closed space of a private domestic banquet, encouraged a choral performance of the skolion. However, the dining facilities used for the sacrificial banquet, whether enclosed (perhaps by a tent) or open-air, would have been just as conducive to a solo performance.

21 See Morgan (1993); Currie (2004). Budelmann (2012) points out that the enkomia of Pindar and Bacchylides often explicitly situate themselves in a sympotic environment, while epinikia make more generalized references to symposia and tend to associate themselves with the larger occasion of the festival banquet. But what Budelmann calls enkomia I would call skolia (including Pi. fr. 122 S.-M.) as many ancient sources do, making the references to symposia quite natural. He is right to point out, however, that these epinikia and skolia (or enkomia) have much in common, especially strategies of praise. It is quite possible that in addition to the skolion (fr. 122 S.-M.) Ol. 13 was performed again at the banquet in the sanctuary of Aphrodite at Corinth where its original external occasion (the victory celebration) would have been re-created through performance, separating 
In Pindar's other skolia - all of which reference a sympotic occasion-we detect a strong correlation between the songs' function and the activities of the banquet, specifically, activities that accompany drinking. ${ }^{22}$ According to Athenaios (427d = Theophrastus fr. 118 Wimmer; Pindar fr. 128 s.-M.):

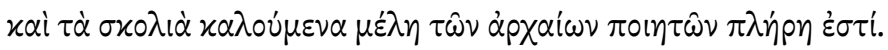

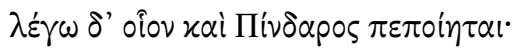

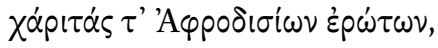

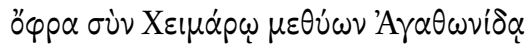

$\beta \alpha \dot{\lambda} \omega \omega$ xó $\tau \tau \alpha \beta \nu \nu$

the songs the ancient poets called skolia are full of [the kottabos]. I mean the kind Pindar composed:

'the charms of Aphrodite's love, so that while getting drunk with Cheimaros

I throw the kottabos for Agathonidas.'

A line preserved by Philodemos (De mus. 4.12), usually attributed to the skolion for Hieron, encapsulates the sympotic experience (fr. 124d s.-M.):

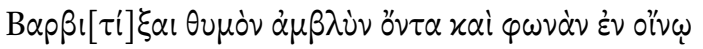

To rouse with the barbitos a mind that is dull along with the voice, over wine.

it generically from the indigenous skolion. On the re-creation or activation of the original occasion, and for the case of epinikia in particular, see Day (2000) 40-41 with relevant bibliography.

22 Only the fragments discussed here are explicitly identified as skolia in ancient sources. It is worth noting that Didymos (fr. 62 Braswell in inscr. a Pi. Nem. 11 Drachmann) associated Nemean 11 with Pindar's $\pi \alpha$ poivi $\alpha$. Pindar's song for Thrasyboulos of Akragas (fr. 124 S.-M. $=$ Athen. $480 \mathrm{oc}, 782 \mathrm{~d}$ ) is not explicitly identified as a skolion, but its content and meter are highly suggestive: in the opening verse Pindar clearly states: 'I am sending a chariot of lovely song for after dinner,' which he says 'may be a sweet goad for your fellow-drinkers'. On the echo of this line in the last verse of Pythian 6 (also composed for Thrasyboulos) see Kurke (1990) 102-103, who calls fr. 124 S.-M. a skolion. Van Groningen (1960) 99-100 suggests that the occasion was a 'fête privée', noting: 'Rien n'indique que le symposion ait présenté un caractère semi-officiel comme celui de Xénophon.' Even so, the message of the song is a universal one: when drinking 'we all sail to a false shore, just the same/then the poor man is rich and the rich man ...' For fuller discussions of this song see Van Groningen (1960) 92-94; Bowra (1964) 232-235. Cf. Bacchylides fr. 2ob s.-M. 
Athenaios records several more lines $(635 \mathrm{~b}-\mathrm{d}=$ Aristoxenos fr. 99 Wehrli; Pindar fr. 125 S.-M.):

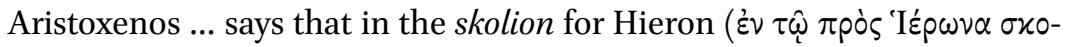
$\lambda(\omega)$ Pindar names the magadis and says 'antiphonal plucking' ... Pindar clearly says that Terpander invented the barbitos, a 'responding-voice' to the Lydian pêktis:

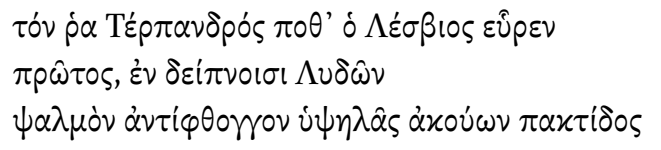

which [barbitos] Terpander the Lesbian first invented, when at Lydian banquets he heard the voice-answering plucking of the high-pitched pêktis. ${ }^{23}$

He also says (Athenaios 512d = Heracl. Pont. fr. 55 Wehrli; Pindar fr. 126 s.-M.):

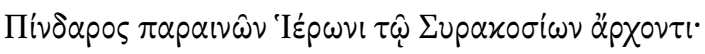

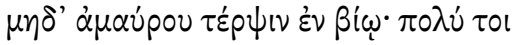

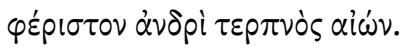

Pindar gives this advice to Hieron, the ruler of Syracuse:

'Do not impair pleasure in life; for by far the best thing for man is a pleasant lifetime.'

Pindar's idealized re-creation of the song's real occasion is augmented by an implicit comparison with imaginary symposia of the distant past, linking Hieron's western Greek present to Terpander's fantastic Lydian east. ${ }^{24}$ The skolion effectively situates the tyrant and his court within a much larger cultural/social/historical matrix. Members of the aristocracy no doubt constituted the bulk of the drinking group, but as the head of the city's power structure and

23 For a more detailed discussion of this skolion see Van Groningen (1960) 112-113. Pindar also composed Olympian 1 and Pythians 1, 2, and 3 for Hieron. On the problematic identification of Pythians 2 and 3, and Pindar's relationship with Hieron see Young (1983); Robbins (1990).

24 On internal references to the external realities of performance in Pindar see Nagy (1990) 94; Carey (2007). According to Schmitt-Pantel (1990) 22-23 Pindar often uses the term $\delta \varepsilon i \pi v o v$ to indicate 'the group around the symposion' as well as the formal banquet itself. 
representative of its sovereignty, the tyrant presided over symposia that were more than just private parties of like-minded hetairoi. The so-called 'princely banquets' of Pindar may be viewed in many respects as civic banquets. ${ }^{25}$ Their skolia spoke to the world - this is most evident in the song for Xenophon-and, in the words of Schmitt-Pantel, reflect 'a system which stresses fundamental values, as much religious as social—in a word, civic values.'. ${ }^{26}$

Evidence relating to the roughly contemporary Attic skolia also makes a fundamental connection between the skolion and wine, though internal references to the sympotic occasion are rare. ${ }^{27}$ We find only two: the voice of $P M G 906$ commands a servant to 'fill it up for Kedon [a martyr who died fighting the tyrants] ... since it is necessary to pour [wine] for good men,' while $P M G 902$ opens by asking no-one in particular to 'drink with me'. Fortunately, external testimony relating to the songs' performance offers an abundance of details. In several comic passages, the sympotic occasion is described or represented on stage, and while the songs themselves are frequently travestied for laughs, the prosaic set-ups appear to reflect everyday practice. In the Wasps, for example, Philokleon is instructed to sing the skolion in a proper fashion and in the proper order, following the libations and initial prayers (1216-1226):

Bdelykleon. Water for our hands! Bring in the tables! We're having our dinner. We've washed our hands. Now we're pouring libations.

Philokleon. For heaven's sake, is the feast just a dream?

Bdel. The auletris has begun her music. Your fellow drinkers are Theoros, Aeschines, Phanos, Kleon, and another foreigner at Akestor's head. With these men for company see that you do a good

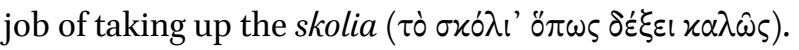

Phil. $\quad$ Are you kidding! I'll do it better than any Diakrian.

Bdel. We'll see. Now then, I'm Kleon and I begin by singing the Harmodios song, and you have to take it up:

'There never was any man in Athens ...'

25 Schmitt-Pantel (1990) 20, n. 42; Vetta (1983).

26 Schmitt-Pantel (1990) 24. We may compare the broad audiences of Pindar's skolia to those of his victory odes, whose purpose was the reintegration of the victorious athlete into the community at large. See Crotty (1982) 121; MacKie (2003) 100-101. Kantzios (2005a) argues that the tyrant's symposia in Athens included members of the community beyond the old aristocracy, such as urban hoplites.

27 Precise dating of the Attic skolia individually or as a group is difficult, if not impossible, but a general date of ca. 514-480 BCE is certainly applicable if somewhat broad. See Bowra $\left(1961^{2}\right)$ 375-376; Thomas (1989) 258-26o; Anderson (2003) 202-203. 
The same pattern is detected in a passage from Antiphanes' Diplasioi (fr. 85 K.-A. = Athenaios 503d) and Plato Comicus' Spartans (fr. 71 K.-A.) where the skolia are sung after the libations but before the kottabos:

A: Have the men already dined?

B: Every single one.

A: Very good. Why don't you run and carry out the tables, while I go and pour out the water for their hands.

$\cdots$

The libation had already occurred and the drinkers were well into it. The

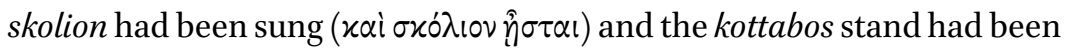
brought out.

The Attic skolia may have lacked structural complexity, but they appear to have been taken seriously as a ritualized component of the symposion's formal progression.

Several more scenes from Aristophanes attest to the popularity of the Attic skolia throughout the polis. The symposion in Aristophanes' Banqueters, where an instructive character commands someone to 'sing a skolion, choosing some-

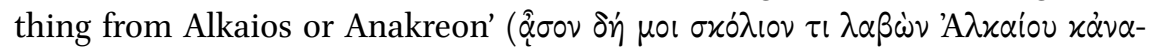

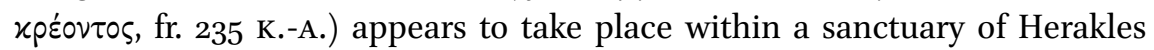
frequented by a group of local demesmen. ${ }^{28}$ References to traditional paraphernalia, including a kottabosstand and garlands, confirm the sympotic context of this scene as the proper occasion for the performance of skolia. ${ }^{29}$ The chorus of Acharnians (978-979) also speak of singing the Harmodios song during festive countryside symposia that may be linked to the Rural Dionysia or Anthesteria. ${ }^{30}$ We hear of the same group of traditional Attic skolia being performed

28 See MacDowell (1995) 27-29; Fisher (2000) 356; Wilkins (200o) 238, 276, 316, 384. The Suda

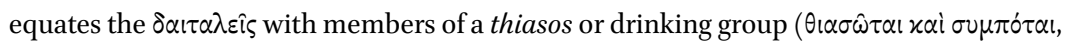
$\delta 125$ Adler). Orion 49.10 Sturz likewise associates the chorus with diners in a local tem-

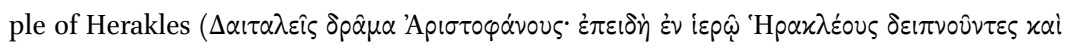

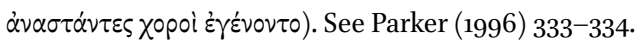

29 The bronze kottabosstand and the garlands mentioned in fr. 231 may serve as an indication that the profligate son was overly familiar with sympotic luxuries. The charisios mentioned in fr. 211 K.-A. is a kind of sesame cake that was most often consumed during late-night sympotic revels. Wilkins (2000) 238, 309-310.

30 On the role of these two festivals in the Acharnians see A.M. Bowie (1993) 26-39 who interprets the play in light of the festivals. Alternatively, Habash (1995) examines the play as evidence for the historical realities of the festivals. See also Sfyroeras (2004). 
in state sanctuaries and civic buildings where citizens from different social strata attended formal symposia. During the final reconciliation scene in the Lysistrata (1236-1237), for example, the Spartan and Athenian delegates ratify their peace treaty with an official ceremony on top of the Acropolis where they continue to celebrate with a formal banquet and symposion that includes the performance of skolia. ${ }^{31}$ The scholiast to Plato's Gorgias 451e (p. 207 Cufalo) also reports that the Harmodios, Admetos, and Telamon songs were routinely performed 'over cups' in the Prytaneion at Athens.

Finally, Aristotle's song to Hermeias ( $P M G$ 842), 'sung everyday in the syssitia'

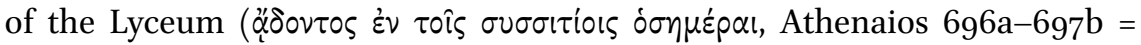
Hermippos fr. 48 Wehrli), was identified by some in antiquity as a skolion. Others called it a paian and accused Aristotle of impiety for treating its human subject as if he were a god. ${ }^{32}$ The song's classification, which is still being debated today, is illuminating all the same because it gives us some idea of what could be counted as a skolion in the minds of ancient critics; whether or not Aristotle composed it with a specific genre in mind or created a kind of hybrid as several modern scholars posit, the song must have exhibited enough characteristics of the skolion to make that label viable. ${ }^{33}$ Athenaios, relying on the third-century в В $\mathrm{E}$ biographer Hermippos and likely echoing Aristotle's own defense, tells us that the song lacked the standard paianic refrain and 'displays none of the characteristics of the paian, but is a certain type of skolion'. He may have added that, like all of Pindar's skolia, Aristotle's song was composed in dactylo-epitrite meters, ${ }^{34}$ and like several Attic skolia laments the death of

31 'If someone sang the Telamon song where the Kleitagora was required, we applauded' ( $\varepsilon i$

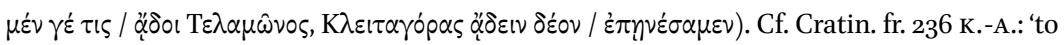
sing the Kleitagora when the aulos plays the Admetos song'. Such confusion suggests that both songs shared a similar rhythm and melody. The Admetos song and the Telamon are both in Greater Asclepiads. Kugelmeier (1996) 45-49.

32 Aristotle's accusers, Eurymedon and Demophilos, appear not to have been entirely successful in their prosecution. For the text and analysis of this song and the ancient controversy over its classification see Bowra (1938); Harvey (1955) 173-175; Renehan (1982); Rutherford (2001) 90-97; Ford (2011).

33 Didymus (in Dem. 10.32) and Diogenes Laertius (5.4-6) both cite the text and refer to the song as a paian and a hymn. Most recently, Ford (2011) 86-9o has revived and expanded the view that Aristotle's song is a kind of hybrid whose genre 'was up for renegotiation when it was performed in new places'.

34 Cf. Harvey (1955) 174: 'the great majority of the poems known to have been $\sigma x \dot{\partial} \lambda \iota \alpha-v i z$. all those of Pindar, all except one of the supposed $\dot{\varepsilon} \gamma x \dot{\omega} \mu \mu \alpha$ of Bacchylides, and the $\sigma x \dot{x}^{\lambda} \lambda_{10 \mathrm{~V}}$ of Aristotle—are in a straightforward dactylo-epitrite meter.' 
virtuous heroes like Achilles and Ajax (13-14; cf. PMG 894, 898), attempts to confer immortality upon its martyred subject (17-21; cf. $P M G$ 894, 896), and offers a bit of gnomic advice about the best thing in life for a mortal, in this case divine Arete (1-2; cf. Athen. 694c; $P M G$ 889-892, 903). In other words, Aristotle's song to Hermeias follows a very similar pattern of composition and performance as the one detectable in the larger corpus of surviving skolia, most notably with respect to content and style.

\section{Content}

Given the skolion's proximity to libations, it is no surprise that several of the Attic skolia address gods and heroes or provide various facts about the deities' lives and their ideal relationship with the drinking group:

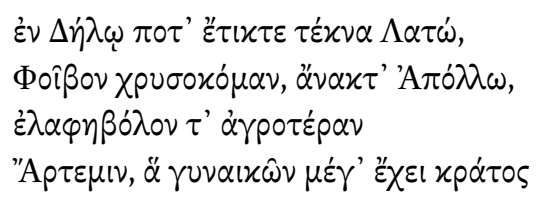

In Delos Leto once bore children, golden-haired Phoebus, lord Apollo, and the shooter of deer, the huntress Artemis, who holds great power over women.

PMG 886

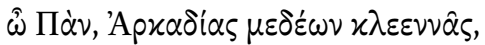

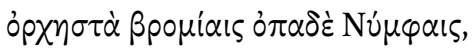

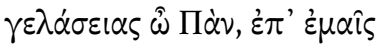

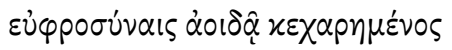

O Pan, ruler of glorious Arcadia, dancer, companion of the Bacchic Nymphs laugh, o Pan, at my merriment rejoicing in my song.

PMG 887

Others offer proverbial advice and maxims in accordance with Artemon's description of the skolion's characteristic didactic function:

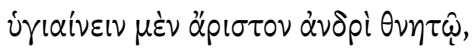

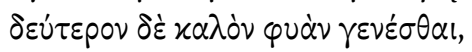




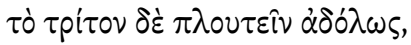

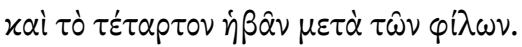

Health is best for a mortal man, second, to be beautiful in stature, third to be wealthy without guile, and fourth to be young with one's friends.

$P M G 890$

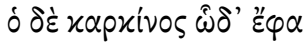

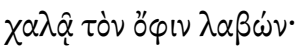

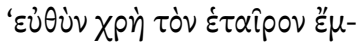

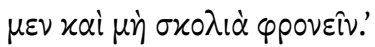

The crab spoke thus

taking the snake in its claw,

'a comrade ought to be straight

and not think crooked thoughts.'

$P M G 892$

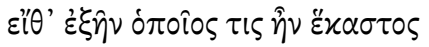

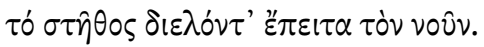

$\varepsilon \dot{\sigma} \sigma \delta \delta \nu \tau \alpha, x \lambda \varepsilon i \sigma \alpha \nu \tau \alpha \pi \dot{\lambda} \lambda เ v$,

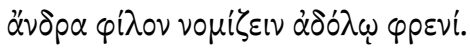

If only it were possible to see what everyone is really like by opening his breast, and looking at his mind to close it back again

and consider the man to be a friend with an honest heart. ${ }^{35}$ $P M G 889$

While the Attic skolion to health (PMG 890) declares outright what the best thing in life really is, Pindar's skolion for Hieron (see above) offers a competing gnomic pronouncement declaring that the best thing for man is a pleasant

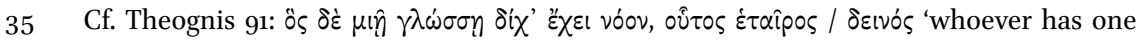

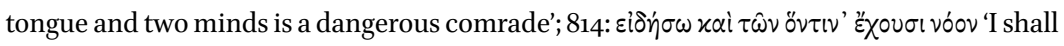
see what kind of mind they have'. Pistos among friends, or the lack thereof, is a consistent theme throughout the Theognidea. See in general Donlan (1985). 
life. Timokreon's moralistic tirade against the evils of wealth follows the same gnomic trajectory. According to a scholiast on Acharnians (532 Wilson):

The poet Timokreon of Rhodes wrote a skolion [PMG 731] like this against

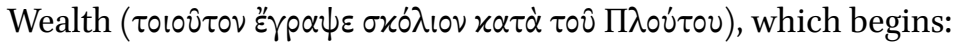

$$
\begin{aligned}
& \omega^{\prime} \varphi \varepsilon \lambda \varepsilon^{\prime} \nu \sigma^{\prime} \hat{\omega} \tau \cup \varphi \lambda \dot{\varepsilon} \Pi \lambda{ }^{\prime} \nu \tau \varepsilon \\
& \mu \eta \dot{\prime} \tau \varepsilon \hat{\eta} \mu \eta^{\prime} \tau^{\prime} \dot{\varepsilon} \nu \theta \alpha \lambda \dot{\alpha} \sigma \sigma \eta \\
& \mu \eta \tau^{\prime} \text { हे } \nu \dot{\eta} \pi \varepsilon i \rho \omega \varphi \alpha \nu \eta \hat{\mu} \mu \varepsilon,
\end{aligned}
$$

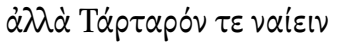

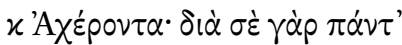

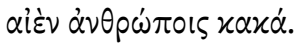

Long before Timokreon's song made the rounds over wine, however, Pythermos (who probably lived during the first half of the sixth century вСЕ) ${ }^{36}$ proclaimed in his only surviving skolion that all else is nothing next to gold (PMG 910):

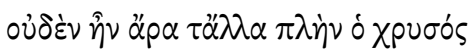

Other things are as nothing except gold.

\section{Style: Meter}

We also detect in the surviving corpus of skolia a limited choice of metrical patterns. Just as subsequent songs picked up Pythermos' moralizing tone, later composers of skolia continued to use the same Aeolic rhythms. The single surviving line of Pythermos' skolion consists of a standard phalaecian verse $\left(-\smile-\cup \cup-v_{-} \sim_{-}=g l i a_{\wedge}\right)$, which also stands at the beginning of a unique metrical pattern used for many of the Attic skolia, consisting of two

36 Athenaios (625b-c) cites a poem by Hipponax or Ananios (ca. 540 BCE) in which Pythermos is mentioned by name; Smyth (1900) 280 . 
phalaecian verses followed by a choriambic dimeter and a final verse with two dodrans (in West's notation): ${ }^{37}$

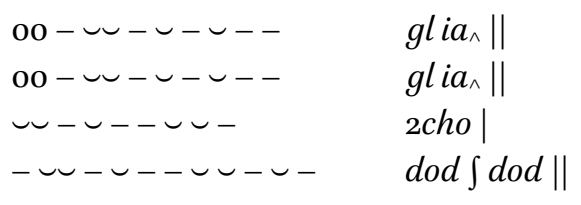

This meter is used for a variety of different songs, including those addressed to the gods (PMG 884-888), the four versions of the Harmodios song (893$896)$, proverbial songs about friendship and human advantage $(889,890)$, and the Leipsydrion lament (907). This scheme likely represents a local Attic tradition used exclusively for the skolion. It appears again in the Ekklesiazousai (938-945), where Aristophanes uses it to construct parodies of democratically charged skolia in the spirit of the Harmodios song. ${ }^{38}$

Otherwise, the collection of twenty-five Attic skolia displays a consistent repertoire of standard, mostly Aeolic meters, including 'major Asclepiads,' i.e. choriambically expanded glyconics ( $P M G$ 897, 902, 903, 904, 905, 908), ${ }^{39}$ one Alcaic stanza ( $P M G$ 891), which seems to be an alternative version of an older song (Alc. fr. $249.6-9$ L.-P.) that has been adapted to the Attic dialect, ${ }^{40}$ a simple piece composed in pure glyconics (892), ${ }^{41}$ and a single elegiac couplet (9o6).

$37 \quad$ West (1982) 59 .

38 See Ussher (1973) 206-207.

39 On this meter see West $(1982) 3^{2-33}, 192$.

40 The Attic version of $P M G 891$ runs as follows:

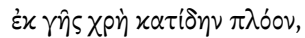

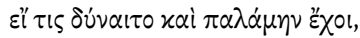

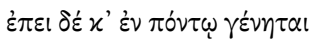

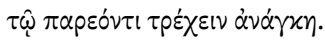

One ought to seek a fair voyage from the land

if one is able and knows how,

but when one is already at sea

it is necessary to run with the present condition.

The papyrus containing Alkaios' song in the Aeolic dialect (P.Oxy. 2298) suggests that these lines originally formed part of a larger composition. The stanza's adapted form in the collection of Attic skolia served as a general song of advice recommending the utility of foresight and perseverance, thus conforming to the skolion's characteristic content and general style. Hansen (1987) 108-109 speculates that this song was revived in Attica during Peisistratos' campaign against Pittakos for the possession of Sigeum.

41 West (1982) 6o describes this meter as 'two telesilleans and a dovetailed pair of glyconics'. Fabbro (1995) 53 . 
We also find a somewhat unusual yet undemanding pattern (PMG 898-901) consisting of a dovetailed glyconic and a dodrans with a second expanded line of the same rhythm: ${ }^{42}$

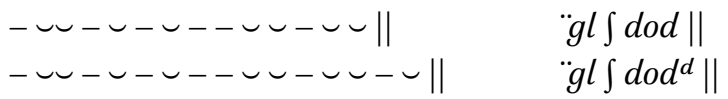

It is no coincidence that the three additional poems of Alkaios that are called skolia in the fifth and fourth centuries BCE were composed in 'major Asclepiads' (fr. 345; 348 L.-P.), and expanded glyconics, otherwise known as the fourteensyllable Sapphic (fr. 141 L.-P.). ${ }^{43}$ Timokreon's single surviving skolion against wealth ( $P M G$ 731) composed in trochaic dimeters also falls squarely within the Aeolic tradition.

We may notice that the straightforward glyconic-based metrical patterns of these Attic skolia are relatively simple, easy to sing, and, as we shall see, conducive to a relaxed melodic pattern. The ease and frequency of these standard metrical structures reflect the 'simple nature of their composers' (Athen. $693 \mathrm{f}$.; see above) and attest to the widespread popularity of such songs throughout the Attic population. ${ }^{44}$ Indeed, the somewhat common, even folksy language of the Attic skolia has not gone unnoticed. Martin West remarks, '[v]ersification in these ditties is a little lax', pointing out, for example, that the $x \alpha$ in in $P M G$ 893.2, 895.2, 896.2, and 907.3 resists elision. He also notes a peculiar pronuncia-

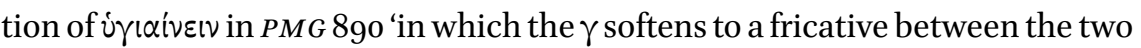
close vowels and a y-glide develops after it: hüg-y(i)',45 Although Pindar's skolia composed in straightforward dactylo-epitrite are more complex than the bulk of these short Aeolic songs, they are relatively simple compared to his epinikia and, we might even say, 'relaxed. ${ }^{46}$ It would seem that even Pindar respected an implicit expectation that a skolion ought to be easy to sing and readily followed.

\footnotetext{
42 West (1982) 60.

43 MacDowell (1971) 291-292.

44 Cf. West (1992) 349 n. 98: 'It can be observed from the meters that there were certain favorite tunes that were used again and again.'

45 West (1982) 18.

46 As Van Groningen (1960) 103 says of his skolion for Hieron (frr. 124d, 125, 126, 128 s.-M.): 'La structure est très simple.'
} 


\section{Style: Mode}

Lyric style may be understood, according to Gregory Nagy, as 'the interaction of phraseology, rhythm, and modes', or diction, meter, and melody (logos, rhythmos, harmonia), the three components of song Plato outlines in the Republic (398d). ${ }^{47}$ Closely related to a song's rhythmic qualities are its interdependent modes, or the distinctive harmoniai underlying its melodic performance. This too is an integral part of the genre's identity. ${ }^{48}$ Both the Lydian and Ionian modes are expressly associated with the skolion and are the only modes known to have been used in their composition. In fact, the invention of the Ionian mode is associated with Pythermos' skolia, as Athenaios reports $(625 \mathrm{c})$ :

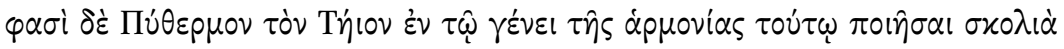

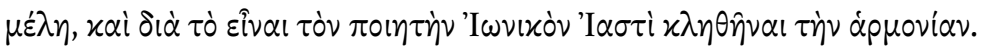

They say that Pythermos of Teos composed skolia in this type of harmoniai, and because the poet was from Ionia the harmony was called Ionian.

While this anecdote probably lacks genuine historical veracity, it does prove two crucial points about the nature of the genre. First, it shows that later generations formulated a separate history of the skolion to account for its unique status: Terpander is credited with originally inventing the form while Pythermos is said to have added the Ionian harmonia to its compositional tradition. ${ }^{49}$ Such quasi-mythical stories reflect the actual process of pan-Hellenization. ${ }^{50}$ Second, this etiological story confirms that certain harmoniai (in this case

$47 \quad$ Nagy (1990) 51.

48 Aristotle (Pol. 1342b) associates the dithyramb with the Phrygian mode, telling us that Philoxenos tried to compose one in the Dorian mode but was forced back into the appropriate Phrygian because the nature of the genre demanded it. However, as West (1992) 181 and Wallace (2005) point out, an Athenian dithyramb produced during the first half of the fifth century вСЕ was performed with 'Dorian auloi' [i.e. with a Dorian mode] at the Dionysia; the victory and the performance are described in an epigram (Anth. Pal. 13.28). Nevertheless, Philoxenus must have had a compelling reason for returning to the preferred mode.

49 On Terpander's invention of the skolion see Van Groningen (1960) 118, Bowra $\left(1961^{2}\right) 131$ n. 5 , Nagy (1990) 358, and Gostoli (1990) 89-90, 112, 132, who associates a fragment attributed to Terpander (fr. 3) with the skolion.

50 As Nagy (1990) 86-91 has shown, the gradual systematization of the major genres and musical elements of the Greek song-making tradition were explained through later myths and stories about early musical innovations and quasi-mythical inventors like Terpander, Arion, and Olympus. 
the Ionian) were associated with the skolion and served as a stylistic genre marker similar to that of meter. ${ }^{51}$

Pindar's skolia point to a second distinctive harmonia that came to define the skolion's generic identity. In his skolion for Hieron, Pindar tells how Terpander invented the barbitos after hearing the pêktis at Lydian banquets (fr. 125 S.M.; see above). Here, the internal reference to Lydian music and festivities signals the composition's own musical tradition, specifically, I would argue, its Lydian harmonia. Normally, the Aeolian and Dorian modes correspond to like meters such as Aeolic and the Dorian dactylo-epitrite, but the Lydian mode is adaptable to both, and in at least one other Pindaric composition (Nemean 8) it is again coupled with dactylo-epitrite. ${ }^{52}$

Plato links the Lydian and Ionian harmoniai in the Republic (398e-399a) when discussing the various melodic patterns and their moral impact upon the human psyche. ${ }^{53} \mathrm{He}$ begins by explaining the interdependence of a song's three constituent elements, declaring that its 'mode and rhythm must necessarily fit

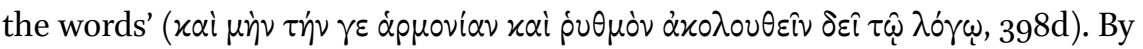
way of example, he draws attention to the inherent connection between the definitive content of poetic laments and the innate 'lamentatory' qualities of

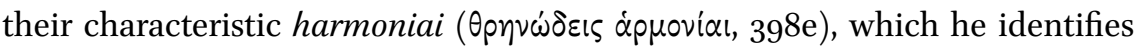
as the Mixolydian and Syntonolydian. After banning laments and threnodic modes from his ideal city, Plato turns his attention to drunkenness and sloth,

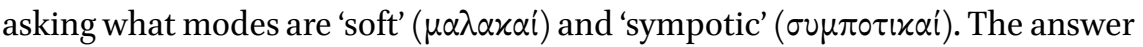
is of course the 'Ionian and Lydian, which are called lax' ('I $\alpha \sigma \tau i$ ', $\hat{\eta} \delta$ ' ö $\varsigma$, xai

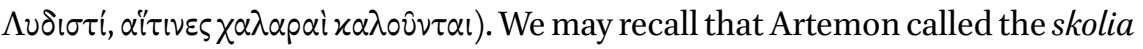

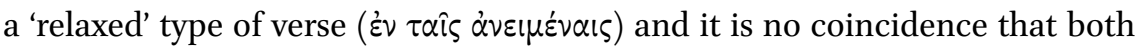

$5^{1} \quad$ Dupont (1999) 84 makes this interesting observation in reference to the skolion's imagined invention: 'The association of Terpander, believed to have evolved musical techniques, once the music of a song had been separated from its words, proves that the skolion was a musical form, not a type of text.' I agree with her basic statement, that the skolion was a melodic phenomenon, but I must disagree with her general observation that 'when the heading skolion is used to assemble texts, it in fact covers more or less anything and everything'.

52 On the correlation between internal references to 'ethnic' instruments and a poem's own mode see Nagy (1990) 94-95. Other references to the Lydian harmonia occur in songs composed in Aeolic meters (Ol. 14; Nem. 4).

53 Plato lists the Ionian, Dorian, Phrygian, Lydian, Mixolydian, and Syntonolydian. Aristides Quintilianus (1.9 = pp. 15-19 Winnington-Ingram) also discusses this list of modes, often called the 'Damonian scale'. West (1992) 174 suggests that they were first described by Damon, Perikles' music teacher. 
Plato and Aristotle use nearly identical descriptions to explain the same two harmoniai normally associated with sympotic songs. Aristotle recognized the relaxed quality of the Lydian mode, but criticized Plato for censuring the easy harmoniai as being conducive to drunkenness (Pol. 1342b). He points out that 'the relaxed harmoniai' ( $\tau \dot{\alpha} \varsigma \dot{\alpha} v \varepsilon \mu \mu \dot{\varepsilon} v \alpha \varsigma \dot{\alpha} p \mu o v i \alpha \varsigma)$ have the effect, not of frenzied intoxication, but of the 'sluggishness' ( $\dot{\alpha} \pi \varepsilon i p \eta x v i \alpha \varsigma)$ that results from the routine consumption of wine and like wine are valued for their power to amuse and relax. They are especially suitable for older people who may have trouble

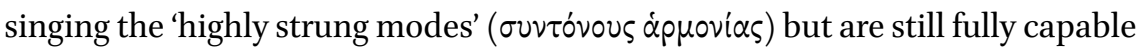
of performing with the easier relaxed harmoniai. Aristotle also ascribes to the Lydian mode in particular a kind of 'orderly' ( có$_{\mu \mu \circ \nu)}$ ) and 'educative' ( $\pi \alpha \iota \delta \varepsilon i \alpha \nu$ ) quality, which accords well with the skolion's didacticism.

\section{Vase-Painting and Performance}

The generic formation of the skolion, founded primarily on the drinking occasion and specific combinations of meter and mode, is likely to have coalesced in the sixth century вСЕ, roughly some time between Pythermos and the appearance of the Attic skolia; it is difficult to be more precise. The early history of the genre was obscure even in antiquity, prompting minds like Pindar's to mythologize its origins through the figure of Terpander. Although recorded texts and references to the genre from the archaic and early classical periods are rare indeed, insight into this period of the skolion's history, both real and imagined, can be garnered from early red-figure vase-painting, which helps to fill some of the gaps in our literary record. ${ }^{54}$ The earliest and arguably most comprehensive picture of the skolion's original performative matrix appears on a red-figure kalyx-krater by Euphronios dated to ca. 500 BCE. ${ }^{55}$ An elaborate symposion illustrates the entire vase, populated on the obverse by a number of reclining figures and a standing auletris, all with their names inscribed (fig. 6.1a). They are, from left to right, Tho[u]demos, Melas, Suko (the auletris), Smikros (often identified as the vase-painter), and Ekphantides, who tilts back his head beneath an upraised right arm and sings a song to Apollo (fig. 6.1b). ${ }^{56}$ The inscribed words

54 An M.A. thesis by P.J. Anderson, 'Verse-Scraps on Attic Containers and the Practice of the 'Skolion': the Material Evidence in its Literary Context' (1997, University of Ottawa) provides a convenient catalogue of poetry fragments on Attic vases associated with symposia. Munich 8935; $A R V^{2}$ 1619. First published by Vermeule (1965).

$5^{6}$ On the significance of these names see Vermeule (1965) 34; Neer (2002) 111-112. 


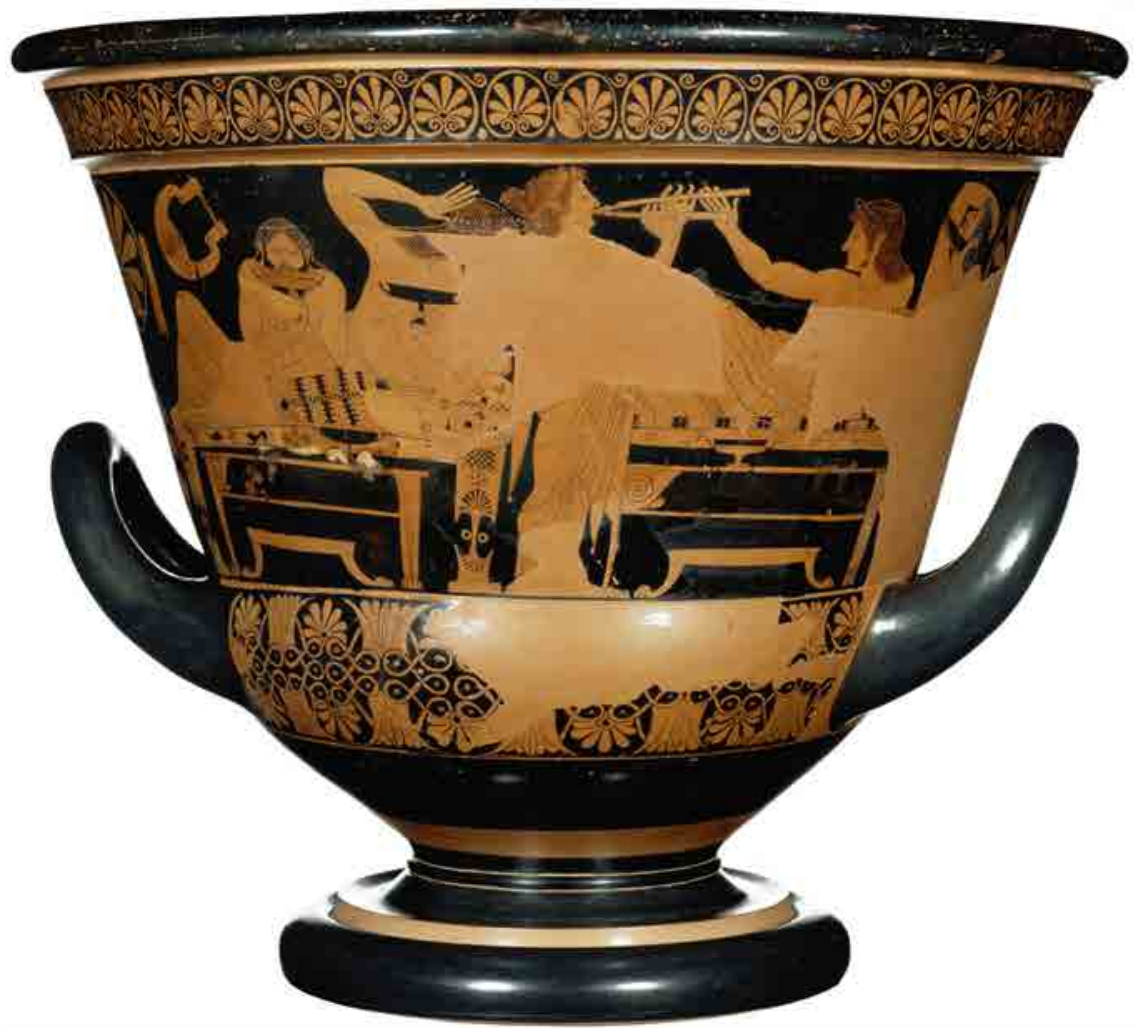

FIG. 6.1A Red-figure krater by Euphronios

MUNICH, STAATLICHE ANTIKENSAMMLUNGEN UND GLYPTOTHEK 8935

issue forth from his mouth in retrograde letters: OПO $\Lambda$ ON $\Sigma$ ЕГЕКАIMAKAI

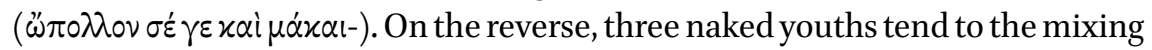
and serving of wine.

Sir John Beazley was the first to identify the inscribed song as a skolion, ${ }^{57}$ followed by Emily Vermeule who drew attention to some stylistic parallels among the Attic skolia, including the song to Pan that begins with a similar address ( $P M G$ 887), and the song in honor of Apollo and the Delian triad ( $P M G$ 886, see above). ${ }^{58}$ The sequence of syllables preserved on the vase is equivalent to a glyconic $(---\smile \cup-\smile-)$ and when fully expanded with three more syllables would

57 Beazley $\left(A R V^{2} 1619\right)$ first suggested that the line be restored as a Phalaecian verse and offers

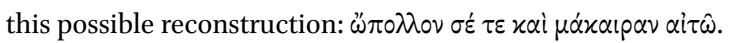

$5^{8}$ Vermeule (1965) 38-39 suggests that the inscribed verse may have represented 'another part' of this Apolline skolion, perhaps an additional set of verses that capped it. She 


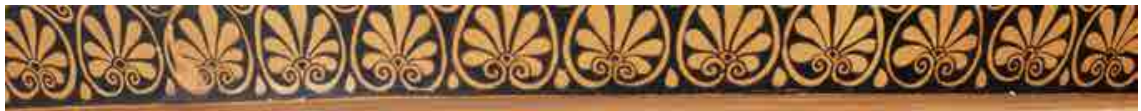

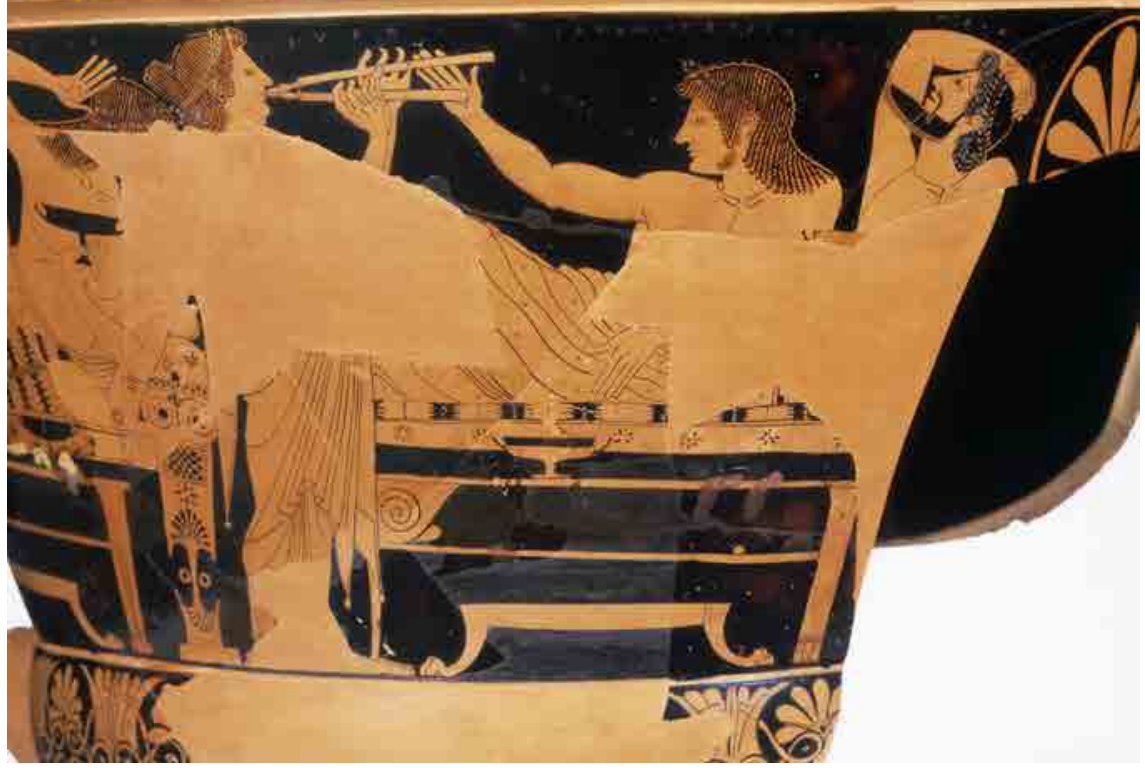

FIG. 6.1B Detail of red-figure krater by Euphronios

MUNICH, STAATLICHE ANTIKENSAMMLUNGEN UND GLYPTOTHEK 8935

represent a phalaecian verse of the kind that stands at the beginning of so many Attic skolia. It is the song's occasion, however, that interests Euphronios and helps us further identify the verse as a skolion. The elaborate equipment and the large scale of the wine service suggest a rather formal, somewhat expanded occasion redolent of the semi-public archaic banquets and symposia explicated by Schmitt-Pantel. Such gatherings were not strictly private affairs, since they normally involved equal members of the community whose actions reflected the larger social structure of the polis. ${ }^{59}$ The labeled presence of a

offers several possible reconstructions of the incomplete line, including this promising

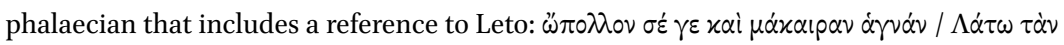

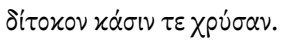

59 Schmitt-Pantel (1990), (1993) 17-31 has shown that images of reclining figures on archaic vases depict a montage of an extended event that incorporates elements from both the banquet and symposion. Schmitt-Pantel (1993) 31: 'ces superbes scènes archaïques expriment les différentes facettes de la convivialité archaïque en en soulignant les fonctions religieuses, sociales et civiques'. Such events should not be divided into public and private, banquet and symposion, but should be understood as a continuum of 'the Archaic aris- 
banausic vase-painter (Smikros) at the symposion contrasts with the larger image of aristocratic leisure, leading some scholars to interpret this scene as a subversion of elite culture or an imaginary world populated by the painter's fictional persona; either way, the skolion seems to lend the image a touch or verisimilitude just as the elaborate couches and wine-cups do. ${ }^{60}$ As I argue elsewhere, short simple skolia of this kind were most often associated with the common classes and popular symposia in fifth-century вСе Athens and so Ekphantides' inscribed song is in tune with the apparent non-elite grouping of painted symposiasts. ${ }^{61}$ Later, during the classical period, divergent sympotic manners became a common source of amusement: in the Wasps, for example, the boorish Philokleon, who is laughably unfamiliar with the eastern clothing stereotypically worn at aristocratic drinking parties and who 'never learned to play the kithara' (959), is nevertheless adept at singing the Attic skolia to the accompaniment of an aulos (1131-1169). ${ }^{62}$ Perhaps a similar contrast exists (whether intended or not) in the image of Smikros and his companions singing a traditional skolion without a lyre against the backdrop of a luxurious symposion.

We may also ask if the relaxed modes that characterize the genre are detectable in Euphronios' imagery. I think they are. Ekphantides sings a skolion in relaxed glyconics as Thoudemos takes a long, deep drink of wine, looking away from Ekphantides and out toward the spectator. His aloof Dionysiac posture seems to reflect the imaginary music filling the room. It surely is not the Apolline content of the skolion's narrative that provokes Thoudemos, but the

tocratic banquet' that included all the members of the egalitarian community: SchmittPantel (1990) 23-24.

6o For example, Neer (2002), 87-117 argues that the insertion of potter-portraits into elite environments transgresses the normal social order and is otherwise 'ideologically impossible'. However, it seems dubious to rely on the opinions of reactionary elites like Plato and Xenophon (as Neer does) for a wholesale description of the social attitudes of an entire city, especially a democratic one like Athens. Hedreen (2014), on the other hand, argues that Euphronios' Smikros functions as an imaginary alter-ego similar to the competing personas adopted by the iambists. See also Topper (2012) 147-153.

61 Jones (2014). Although the Attic skolia probably originated within popular symposia dominated by non-elites, they were in all likelihood known and performed by aristocrats through the 'common culture' of classical Athens. Gaunt (2014) has shown that vase inscriptions are normally drawn from a shared oral tradition as opposed to attributed works of literature; simple skolia like the one Euphronios has inscribed no doubt emerged from the same common tradition and were likely more familiar to vase-painters than compositions by named elite poets.

62 Cf. Swift (2010) 44-48. 
relaxed Lydian or Ionian harmonia that Plato said was conducive to drinking and that Aristotle associates with the relaxing, intoxicating effects of wine. ${ }^{63}$

\section{Visions of Terpander}

The images and inscribed verse on the Euphronios krater explicated above provide the earliest surviving evidence for the emergence of a stable pattern of composition and performance that ultimately led to the full recognition of a distinct genre called the skolion. Although the historical process of generic formation is mostly lost to us, images of the skolion's development continued to echo throughout the collective memory of successive generations of singers and audiences, surviving today as part of the historicizing mythology of the Greek musical tradition. It is fair to say that one of the clearest indicators of a fully recognized genre in Greek music is the development of a pan-Hellenic creation story. Arion's invention of the dithyramb is one of the best examples of this phenomenon, and, as I have noted throughout this paper, by Pindar's day the form and function of the skolion was likewise explained through the quasi-mythical devices of primordial musicians like Terpander. But, as Timothy Power has observed, there are no extant precedents for Pindar's attribution of the barbitos and skolion to Terpander, leading him to argue that the poetic image of a sympotic Terpander is merely a self-interested reflection of Pindar himself. Pindar's songs are more elaborate than the typical short skolion, including those attributed to Sappho, Alkaios, and Anakreon, and the professional poet may indeed have required a more appropriate model for his work, but is this version of Terpander nothing more than a construct of Pindar's imagination? ${ }^{64}$ It seems unlikely that he would have made such attributions ex nihilo; at the very least we may surmise that a common tradition had already traced the origins of the skolia back to the song culture of archaic Lesbos, and from there it is easy to imagine others associating the eastern overtones of Terpander's music with the phenomenon of singing skolia in the Ionian and Lydian modes. Early evidence linking Terpander to the invention of the barbitos and skolion might even be found in archaic red-figure vasepainting.

63 Frontal faces in Attic vase-painting often reflect the mood of figures captivated by music as well as wine. Thoudemos represents both: he is held in rapture by sympotic modes conducive to drunkenness. See Frontisi-Ducroux (1995) 95-97, fig. 42; cf. Korshak (1987) 11-14, 55 .

64 Power (2010) 410-414 hypothesizes that Pindar's image is based on a tradition in which Terpander sang at aristocratic symposia and public messes at Sparta. 
A large cup by the Epeleios Painter made around 500 вСе (fig. 6.2a) may contain allusions to the sympotic aspects of Terpander's life. ${ }^{65}$ In the center of the composition, two men, one young and smooth, the other bearded, flank a mammoth krater planted firmly on the ground; they are surrounded by a group of happy revelers highlighted by a number of kalos inscriptions floating about their heads and shoulders. The youth sips from a large skyphos while his free hand hovers over the mouth of the larger vessel. The bearded man approaches from the right, legs bent, holding out with both hands a tortoise-shell barbitos. ${ }^{66}$ His dress is eastern and exotic: a Lydian turban (or mitra) covers his head while a long himation drapes his body. The older man's emphatic presentation of the barbitos draws more attention to the instrument than to the krater below, which is partially hidden behind his left leg. ${ }^{67} \mathrm{His}$ actions and appearance are quite unique. ${ }^{68}$ The fashionable musician does not play his instrument or hand it to the youth in front of him, but looks as though he were parading the barbitos through the midst of the assembled symposiasts. Images like these are normally interpreted as genre scenes depicting a typical symposion and kômos, ${ }^{69}$ but I would like to propose a new interpretation of this particular image. Could the bearded man in the center of the composition be Terpander introducing his newly invented barbitos to a crowd of mainland Greeks? From the surrounding inscriptions, the word $\mathrm{KA} \Lambda \mathrm{O} \Sigma$ is written directly in front of the bearded figure's face, perhaps performing double duty as the voice of Terpander declaring that his instrument is beautiful. Images of famous poets are far from unknown in archaic and classical vase-painting. Sappho, Alkaios, and Anakreon were especially popular among the makers of sympotic pottery; Archilochos (or Hesiod) and a little known lyric poet named Kydias

65 Munich 2619a; $A R V^{2}$ 146.2. Lissarrague (1990b) 200-201, plate 19b; Bundrick (2005) 82-83.

66 For the barbitos and its representation in Attic vase-painting see Snyder (1972); Maas and Snyder (1989) 113-138; Bundrick (2005) 21-25. The instrument is most often associated with drinking, the kômos, and general sympotic revelry. It is above all an instrument of leisure.

67 Lissarrague (1990a) 32 notes: 'The two figures are making representative gestures that indicate the importance of both the lyre and the krater.' For representations of eastern poets in Athenian vase-painting see also Yatromanolakis (2008) 131-139.

68 In the many images of male figures, mostly youths, holding or playing a barbitos, often in front of a krater, they are normally shown holding the instrument close to their body, not out and away from it. For instance, in the tondo of a red-figure cup by the Triptolemos Painter (Louvre G 245, ARV 366, 86) a youth holding a barbitos stands between a herm and a krater, indicating an outdoor setting similar to the one on the Epeleios Painter's cup, but here the player's gesture is calm and static. Lissarrague (1990a) 32-37, fig. 22.

69 Cf. Lissarrague (1990a) 32-33; (199ob) 200-201; Bundrick (2005) 82-83. 


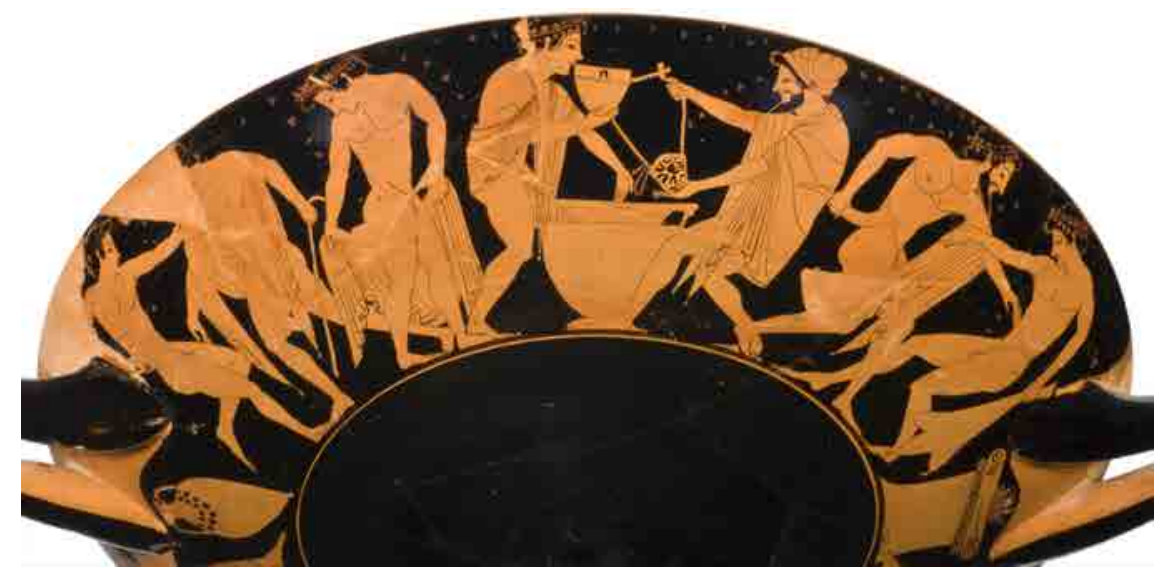

FIG. 6.2A Red-figure kylix by the Epeleios Painter

MUNICH, STAATLICHE ANTIKENSAMMLUNGEN UND GLYPTOTHEK 2619A

have also been identified..$^{70}$ We should not be surprised, then, to find an image of the primeval poet Terpander on an early red-figure vase.

Terpander was originally from Lesbos, though Pindar's tradition would have him traveling to Lydian territories picking up local traditions before making his way to the Greek mainland where he is said to have carried out many more innovations. ${ }^{71} \mathrm{He}$ is credited with being the first to organize Greek music and inventing the system of kitharodic nomes, which probably occurred once he had reached Sparta. He is also said to have increased the number of strings on

70 Sappho: hydria in Six's technique (Warsaw 142333, $A R V^{2}$ 300, Para 246); red-figure kalathos psykter by the Brygos Painter (Munich 2416, $A R V^{2} 385$ and 1649); red-figure hydria attributed to the Group of Polygnotos (Athens 126o, $A R V^{2}$ 106o, Para 445); red-figure kalyxkrater by the Tithonos Painter (Bochum s 508). See Yatromanolakis (2001); Bundrick (2005) 99-102; Yatromanolakis (2008). Alkaios: red-figure kalathos psykter by the Brygos Painter (Munich 2416, $A R V^{2} 385$ and 1649). See Lissarague (199ob) 125-126; FrontisiDucroux and Lissarrague (1990) 218-219. Anakreon (with name inscribed): fragment of a red-figure krater (Copenhagen MN 13365, $A R V^{2} 185$ ); red-figure cup by Oltos (London E 18, $A R V^{2} 62,86$ ); lekythos by the Gales Painter (Syracuse $26967, A R V^{2} 36,2$ ). See Boardman and Kurtz (1986); Frontisi-Ducroux and Lissarrague (1990). Yatromanolakis (2001) 16o notes the special popularity of these poets among the general population, which may explain the prevalence of their images on Attic vases during the late archaic and classical periods. For the contested identification of Archilochos (or possibly Hesiod) on a white-ground pyxis by the Hesiod Painter (Boston 98.887) see Clay (2004) 55-57.

71 Though ancient sources assign various birthplaces to Terpander, the more prominent tradition maintained that he was a native of Lesbos. Hellanicus FGrHist 4 F $85=$ Athen. 635e; Suda $\tau 354$ Adler; Marm. Par. Ep. 34. Nagy (1990) 86. 
the lyre from four to seven and to have been the first musician to win a musical contest at the Karneia. ${ }^{72}$ According to this tradition and on the assumption that it was internally coherent, Terpander must have introduced the barbitos to mainland Greece after arriving at Sparta, and either brought the skolion with him or invented it there. It is difficult to locate the Epeleios Painter's symposion geographically, but the detailed setting does give some clues about the scene's temporal location. A wreathed amphora and a smoking altar beneath either of the cup's handles are indicative of an outdoor sanctuary where sacrifice and ritual dining has just occurred, ${ }^{73}$ while the large krater at the center of the scene signals the onset of a symposion and the convivial pleasures that normally followed the deipnon. ${ }^{74}$ The outdoor setting of the painted scene and the apparent lack of couches suggest that the surrounding figures will recline on the ground when they are ready to drink, signaling the kind of ancient primitive symposion Kathryn Topper has explored in black and red-figure vasepainting. ${ }^{75}$ Symposia like these were imagined by the vase-painter to have taken place in the distant past, thus providing a chronologically accurate setting for Greece's first musician.

A pivotal clue in support of Terpander's identification comes from an inscription in the tondo of the cup where a lively satyr fills a garlanded krater from a large wineskin (fig. 6.2b). The inscription above his head $\Sigma$ I $\Lambda$ ANO $\Sigma$ TEPחON can either be read as a participial phrase, 'a silen enjoys himself', or as a title, 'Terpon the silen,76 which may be shorthand for 'Terpander,' whose name means 'he who gives pleasure to men'. ${ }^{77}$ A concentrated slew of additional

72 Ps. Plut. De musica 1132d-1134b, 1140f-1141d; Pollux 4.65 Bethe; Strabo 13.2.4; Hellanikos FGrHist 4 F 85 = Athen. 635e. The Karneia's origins date to the 26th Olympiad, between 676 and 672 BCE. Nagy (1990) 86. See generally Power (2010).

73 Lissarrague (1990b) 204-205 briefly discusses the significance of images that show kraters in close proximity to sacrificial altars, explaining how some painters emphasized the equal distribution of meat and wine within sanctuaries.

74 This scene depicts the drinking stage only, as opposed to an accumulated image of the sacrifice, banquet and symposion that often appears on archaic vases. Schmitt-Pantel (1990). Attic red-figure vases evolved to depict more specific stages and events of the banquet, including sacrifice, libation, feasting, symposion, and kômos. Dentzer (1982); Lissarrague (1990a) and (1990b) 196.

75 Topper (2009) and (2012) 23-52.

76 Lissarrague (1990a) 39 .

77 Nagy (1990) 86. An aulos-playing satyr named Terpaulos (ТЕРПАҮ $О \Sigma$ ) appears on a red-figure amphora by Smikros (Berlin 1966.19) with no obvious allusions to Terpander; however, this does not necessarily preclude the presence of such allusions on the Epeleios Painter's cup. See Lissarrague (1990a) 127. 


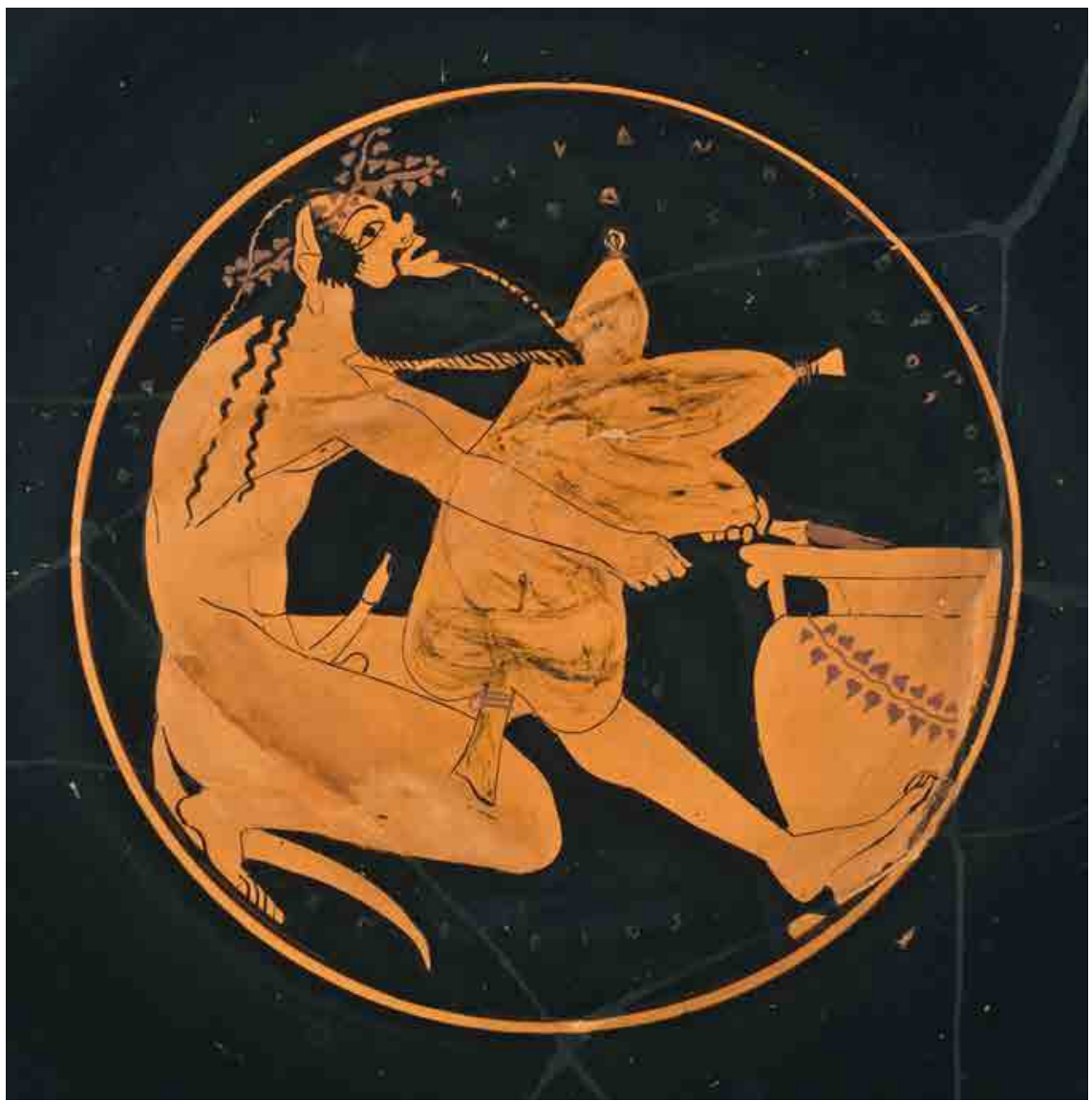

FIG. 6.2B Red-figure kylix by the Epeleios Painter (tondo)

MUNiCH, STAATLICHE ANTIKENSAMMLUNGEN UND GLYPTOTHEK 2619A

words in the tondo complement the visual play that occurs on the outside of the cup. Along the edge of the satyr we read KA $\Lambda \mathrm{O} \Sigma$ EПE $\Lambda$ EIO $\Sigma$ ('Epeleios [the vase-painter] is beautiful') echoing the many kalos inscriptions floating in space above the beautiful young men on the front of the vase. A second inscription above the wineskin informs us that 'the wine is sweet' (HEDY $\Sigma$ OINO $\Sigma) .{ }^{78}$ The actions and very name of the old satyr in the tondo hearken back to the pleasurable scene on the front of the vase where the bearded man holds his barbitos over the krater in a gesture similar to that of the Silen. Has the satyr appropriated the name of the exotic figure on the exterior of the cup,

78 Lissarrague (1990a) 38-39. 
shortening Terpander to Terpon? The use of the Doric dialect in the satyr's inscribed title may further connect his name to Terpander's Doric association. In this play on names, the pleasure of music given by Terpander on the outside of the cup is transferred to the satyr in the tondo, where his erect penis comically resembles a large aulos and further connects him to the matrix of wine, music, and song that defines the symposion. ${ }^{79}$ Both figures stand out as harbingers of sympotic pleasure, the satyr as a follower of Dionysos and conveyer of wine, Terpander as the inventor of the barbitos and the skolion.

It must be acknowledged, however, that the lack of an explicit name-inscription attached to the figure holding the barbitos leaves any identification of him open to question; and yet, the scene so closely matches the imagery we find in the skolion to Hieron that, at the very least, we may recognize the barbitos player as a kind of precursor to Pindar's Terpander-a prototypical poet from the east delivering the 'exotic' music of his symposion to mainland Greeks. Perhaps aristocratic singers and audiences were already making efforts to distinguish the more refined skolia of expert poets from local popular songs like the Attic skolia. The Epeleios Painter sets the Terpander figure apart from the others on the vase through his Lydian attire, which would have drawn attention to the eastern influences associated with his music and poetry. The mitra he wears is especially symbolic. In a colorful metaphor in Nemean 8 Pindar compares his own musical craft to 'a Lydian mitra embroidered with ringing melody' (8.13$15)$ :

A suppliant, I cling to the sacred knees of Aiakos on behalf of his dear city

and these citizens, bringing

a Lydian mitra embroidered with ringing melody ( $\Lambda \nu \delta^{\prime} \alpha \nu \mu i \tau p \alpha \nu$ « $\alpha \nu \alpha \chi \alpha \delta \dot{\alpha} \pi \varepsilon \pi \circ(x(\lambda \mu \varepsilon \dot{v} \nu \alpha)$,

Nemean glory in the double foot race for Deinias and his father Megas.

This verse refers to both the song and its Lydian harmonia. ${ }^{80}$ Such metaphors also suggest a strong general correlation between eastern melodies, the exotic mitra, and the ornamented poets who wear them. ${ }^{81}$ Does the eastern headgear worn by singers and poets in Athenian vase-painting signal the performance of harmoniai like the Lydian and Ionian? Alternatively, does the eastern apparel

\footnotetext{
79 Satyrs also hang aulos-cases from their erect phalloi. See Mitchell (2009) 167-169.

8o See Nagy (1990) 94; Henry (2005) 77.

81 For the mitra and its Lydian associations see Brandenburg (1966); Kurtz and Boardman (1986) 50-70; DeVries (2000) 358-363.
} 
worn by singers on the so-called Anakreontic vases act as a kind of visual metaphor for the eastern melodies they perform? ${ }^{82}$ We may imagine that the barbitos on the front of the Epeleios Painter's cup is tuned to one of the two appropriate modes in preparation for the performance of a skolion (the most common type of song performed over wine).

If this interpretation is correct, then the Epeleios Painter's cup and Euphronios' calyx-krater are indicative of a divergent sympotic culture as early as $500 \mathrm{BCE}$ with two distinct views of the skolion, one absorbed in eastern luxury and expert musicians, the other rooted in a popular song culture conducted by laymen (like Smikros and his companions), but with both following the same pattern of composition and performance that characterized the pan-Hellenic concept of the skolion.

\section{Works Cited}

Anderson, G. (2003). The Athenian Experiment. Ann Arbor.

Bowie, A.M. (1993). Aristophanes: Myth, Ritual, and Comedy. Cambridge.

Bowie, E.L. (1986). 'Early Greek elegy, symposium and public festival'. JHS 106: 13-35.

Bowra, C.M. (1935 $\left.{ }^{1}\right)$. Greek Lyric Poetry. Oxford.

- (1938). 'Aristotle's Hymn to Virtue'. cQ 32: 182-189.

- $\left(1961^{2}\right)$. Greek Lyric Poetry. Oxford. (1964). Pindar. Oxford.

Brandenburg, H. (1966). Studien zur Mitra. Münster.

Budelmann, F. (ed.) (2009). The Cambridge Companion to Greek Lyric. Cambridge. (2012). 'Epinician and the symposion: a comparison with the Enkomia' in

P. Agócs, C. Carey, and R. Rawles (eds), Reading the Victory Ode. Cambridge: 173-19o.

Budin, S.L. (2006). 'Sacred prostitution in the first person' in C.A. Farone and L.K. Mc-

Clure (eds), Prostitutes and Courtesans in the Ancient World. Madison, WI: 77-92.

Bundrick, S.D. (2005). Music and Image in Classical Athens. Cambridge.

82 The scene on the Epeleios Painter's cup has many elements in common with this set of vases, though his barbitos player lacks the kind of extravagant apparel and motions most commonly found in scenes of the 'Anakreontic' type. The closest parallel is found on a redfigure lekythos in Syracuse $\left(26967 ; A R V^{2} 36[2]\right)$ where a bearded barbitos player wearing a chiton and turban and labeled Anakreon is flanked by two naked youths, one of whom carries a large skyphos toward the bearded singer. See Frontisi-Ducroux and Lissarrague (1990) 214-215, 237 who suggest that the name of Anakreon inscribed on the arm of a barbitos on a fragmented red-figure calyx-krater (attributed to the Kleophrades Painter; Copenhagen $\mathrm{MN} 13365 ; A R V^{2} 185$ [32]) acts as a general reference to Anakreontic poetry. 
Carey, C. (1991). 'The Victory Ode in Performance: The Case for the Chorus'. $c P$ 86: 192200.

(2007). 'Pindar, Place, and Performance' in S. Hornblower and C. Morgan (eds), Pindar's Poetry, Patrons, and Festivals. Oxford: 199-210.

- (2009). 'Genre, Occasion, and Performance' in F. Budelmann (ed.) (2009): 2138.

Cingano, E. (2003). 'Entre skolion et enkomion: Réflexions sur le "genre" et la performance de la lyrique chorale grecque' in J. Jouanna and J. Leclant (eds), La poésie grecque antique, Cahiers de la Villa 'Kerylos' 14. Paris: 17-45.

Clay, D. (2004). Archilochos Heros: The Cult of Poets in the Greek Polis. Cambridge, MA.

Collins, D. (2004). Master of the Game: Competition and Performance in Greek Poetry. Washington DC.

Crotty, K. (1982). Song and Action: the Victory Odes of Pindar. Baltimore.

Csapo, E. (2004). 'The Politics of the New Music' in Murray and Wilson (eds) (2004): 207-248.

Day, J.W. (2000). 'Epigram and reader: Generic force as (re-)activation of ritual' in Depew and Obbink (eds) (2000): 37-57.

Dentzer, J.M. (1982). Le motif du banquet couché dans le Proche-Orient et le monde grec du VII $I^{\text {ème }}$ au IV ${ }^{\text {ème }}$ siècle avant J.-C. Paris.

Depew, M. and Obbink, D. (2000). 'Introduction' in Depew and Obbink (eds) (2000): 1-18.

(eds) (200o). Matrices of Genre: Authors, Canons, and Society. Cambridge MA.

DeVries, K. (2000). 'The nearly other: The Attic vision of Phrygians and Lydians' in B. Cohen (ed.), Not the Classical Ideal: Athens and the Construction of the Other in Greek Art, Leiden: $338-363$.

Donlon, W. (1985). 'Pistos philos hetairos' in T.J. Figueira and G. Nagy (eds), Theognis of Megara: Poetry and the Polis. Baltimore: 223-244.

Dupont, F. (1999). The Invention of Literature: From Greek Intoxication to the Latin Book, trans. Janet Lloyd. Baltimore.

Fabbro, E. (1995). Carmina Convivalia Attica. Lyricorum Graecorum quae extant Omnia 11. Rome.

Fisher, N. (2000). 'Symposiasts, fish-eaters and flatterers: Social mobility and moral concerns in Old Comedy' in D. Harvey and J. Wilkins (eds), The Rivals of Aristophanes: Studies in Athenian Old Comedy. London: 355-396.

Ford, A. (2011). Aristotle as Poet: the Song for Hermias and Its Contexts. Oxford.

Fowler, R.L. (1987). The Nature of Early Greek Lyric: Three Preliminary Studies. Toronto.

Fränkel, H. (1973). Early Greek Poetry and Philosophy, trans. M. Hadas and J. Willis. New York.

Frontisi-Ducroux, F. (1995). Du masque au visage. Aspects de l'identité en Grèce ancienne. Paris. 
Frontisi-Ducroux, F. and F. Lissarrague (1990). 'From ambiguity to ambivalence: A Dionysiac excursion through the 'Anakreontic' vases' in D. Halperin, J. Winkler, and F. Zeitlin (eds.), Before Sexuality: The Construction of Erotic Experience in the Ancient World. Princeton: 211-256.

Gaunt, J. (2014). 'The poet and the painter: A hymn to Zeus on a cup by the Brygos Painter' in R. Scodel (ed.), Between Orality and Literacy: Communication and Adaptation in Antiquity. Mnemosyne suppl. 367. Leiden: 101-124.

Gostoli, A. (1990). Terpander: Introduzione, testimonianze, testo critico, traduzione e commento. Lyricorum Graecorum quae exstant 8. Rome.

Habash, M. (1995). 'Two complementary festivals in Aristophanes' Acharnians'. AJPh 116: $559-577$.

Hansen, O. (1987). 'An Attic drinking-song as a possible source for Peisistratus' campaign for the possession of Sigeum in the Troad'. PP 42: 108-109.

Harvey, A.E. (1955). 'The classification of Greek lyric poetry'. cQ 5: 157-175.

Heath, M. (1988). 'Receiving the $x \hat{\omega} \mu \circ \varsigma$ : The context and performance of epinician'. AJPh 109: 180-195.

Heath, M. and M. Lefkowitz. (1991). 'Epinician perofrmance: A response to Burnett and Carey'. CPh 86: 173-191.

Hedreen, G. (2014). 'Smikros and Epilykos: Two comic inventions in Athenian vasepainting' in J. Oakley (ed.), Athenian Potters and Painters III. Oxford: 49-62.

Henry, W.B. (2005). Pindar's Nemeans: A Selection. Munich.

Jones, G.S. (2014). 'Voice of the people: Popular symposia and the non-elite origins of the Attic skolia'. TAPhA 144: 229-262.

Kantzios, I. (2005a). 'Tyranny and the symposion of Anacreon'. $c J$ 100: 227-246. (2005b). The Trajectory of Archaic Greek Trimeters. Leiden.

Korshak, Y. (1987). Frontal Faces on Attic Vase Painting of the Archaic Period. Chicago.

Kugelmeier, C. (1996). Reflexe Früher und Zeitgenössischer Lyrik in der Alten Attischen Komödie. Stuttgart.

Kurke, L. (1990). 'Pindar's sixth Pythian and the tradition of advice poetry'. TAPhA 120: $85^{-107 .}$

(1996). 'Pindar and the prostitutes, or reading ancient "pornography"'. Arion 4: 49-75.

Kurtz, D.C. and J. Boardman (1986). 'Booners' in J. Frel and M. True (eds.), opA 2. GVGetty 3. Malibu: $35^{-70 .}$

Lambin, G. (1992). La chanson grecque dans l'antiquite. Paris.

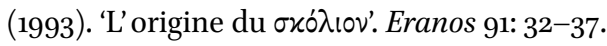

Liapis, V. (1996). Double entendres in skolia: the etymology of skolion'. Eranos 94: 111122.

Lissarrague, F. (1990a). The Aesthetics of the Greek Banquet: Images of Wine and Ritual, trans. A. Szegedy-Maszak. Princeton. 
- (1990b). 'Around the krater: An aspect of banquet imagery' in Murray (ed.) (1990): 196-209.

MacDowell, D.M. (1971). Aristophanes, Wasps. Oxford. (1995). Aristophanes and Athens. Oxford.

Maas, M. and J.M. Snyder (1989). Stringed Instruments of Ancient Greece. New Haven. MacKie, S. (2003). Graceful Errors: Pindar and the Performance of Praise. Ann Arbor. Mitchell, A.G. (2009). Greek Vase-painting and the Origins of Visual Humour. Cambridge. Morgan, K. (1993). 'Pindar the professional and the rhetoric of the $x \omega \hat{\omega} \mu \circ \varsigma^{\prime} . C P h$ 88: 1-15. Murray, O. (ed.) (1990). Sympotica: A Symposium on the Symposion. Oxford.

Murray, P. and Wilson, P. (eds) (2004). Music and the Muses: The Culture of 'Mousikê' in the Classical Athenian City. Oxford.

Nagy, G. (1990). Pindar's Homer. Baltimore.

— (1994-1995). 'Genre and occasion'. Métis 9/10: 11-25.

Neer, R. (2002). Style and Politics in Athenian Vase-Painting. Cambridge.

Parker, R. (1996). Athenian Religion: A History. Oxford.

Power, T. (2010). The Culture of Kitharôidia. Washington DC.

Renehan, R. (1982). 'Aristotle as lyric poet: The Hermias poem'. GRBS 23: 251-274.

Reitzenstein, R. (1893). Epigramm und Skolion: Ein Beitrag zur Geschichte der alexandrinischen Dichtung. Giessen.

Robbins, E. (1990). 'The gifts of the gods: Pindar's third Pythian'. cQ 40: 307-318.

Rutherford, I. (2001). Pindar's Paeans: A Reading of the Fragments with a Survey of the Genre. Oxford.

Schmitt Pantel, P. (1990). 'Sacrificial meal and symposion: Two models of civic institutions in the archaic city?' in Murray (ed.) (1990): 14-33.

(1992). La cité au banquet: histoire des repas publics dans les cités grecques. Rome.

Sfyroeras, P. (2004). 'From sacrifice to feast: A ritual pattern in Aristophanic comedy' in D.L. Cairns and R.A. Knox (eds.), Law, Rhetoric, and Comedy in Classical Athens: Essays in Honor of Douglas M. MacDowell. Swansea: 251-268.

Smyth, H.W. (1900). Greek Melic Poets. London.

Snyder, J.M. (1972). 'The barbitos in the classical period'. $c J 67: 331-340$.

Swift, L.A. (2010). The Hidden Chorus: Echoes of Genre in Tragic Lyric. Oxford.

Teodorsson, S. (1989). 'The etymology of scolion'. Eranos 87:127-132.

Thomas, R. (1989). Oral Tradition and Written Record in Classical Athens. Cambridge.

Topper, K. (2009). 'Primitive life and the construction of the sympotic past in Athenian vase painting'. AJA 113: 1-26. (2012). The Imagery of the Athenian Symposium. Cambridge.

Ussher, R.G. (1973). Aristophanes, Ecclesiazusae. Oxford.

Van Groningen, B.A. (1960). Pindare au banquet. Leiden.

Vermeule, E. (1965). 'Fragments of a symposion by Euphronios'. AntK 8: 34-39. 
Vetta, M. (1983). Poesia e simposio nella Grecia antica. Rome.

Wallace, R. (2005). 'Performing Damon's harmoníai' in C. Harrauer and S. Hagel (eds), Ancient Greek Music in Performance. Vienna: 147-158.

West, M.L. (1974). Studies in Greek Elegy and Iambus. Berlin.

- (1982). Greek Metre. Oxford. (1992). Ancient Greek Music. Oxford.

Wilkins, J. (2000). The Boastful Chef: The Discourse of Food in Ancient Greek Comedy. Oxford.

Wilson, P. (2004). 'Athenian strings' in Murray and Wilson (eds) (2004): 269-306.

Yatromanolakis, D. (2001). 'Visualizing poetry: An early representation of Sappho'. CPh 96: 159-168.

(2004). 'Ritual poetics in archaic Lesbos: Contextualizing genre in Sappho' in D. Yatromanolakis and P. Roilos (eds), Greek Ritual Poetics, Washington DC: 56-70. (2008). Sappho in the Making: The Early Reception. Washington DC. (2009). 'Ancient Greek popular song' in Budelmann (ed.) (2009): 263-276.

Young, D.C. (1983). 'Pindar Pythians 2 and 3: Inscriptional $\pi \circ \tau \dot{\varepsilon}$ and the "poetic epistle"'. HSCPh 87: 31-42. 